\title{
Conditions for Development of the Entrepreneurial Ecosystem in Tourism in the Border Area of the European Union: The Example of the Tri-Border Area of Poland-Belarus-Ukraine
}

\author{
Renata Anisiewicz
}

check for updates

Citation: Anisiewicz, R. Conditions for Development of the

Entrepreneurial Ecosystem in Tourism in the Border Area of the European

Union: The Example of the Tri-Border Area of Poland-Belarus-Ukraine. Sustainability 2021, 13, 13595. https:/ / doi.org/10.3390/su132413595

\section{Academic Editors: Elżbieta}

Grzelak-Kostulska and Jadwiga

Biegańska

Received: 5 November 2021

Accepted: 6 December 2021

Published: 9 December 2021

Publisher's Note: MDPI stays neutral with regard to jurisdictional claims in published maps and institutional affiliations.

Copyright: (C) 2021 by the author. Licensee MDPI, Basel, Switzerland. This article is an open access article distributed under the terms and conditions of the Creative Commons Attribution (CC BY) license (https:// creativecommons.org/licenses/by/ $4.0 /)$.
Division of Regional Development, Institute of Socio-Economic Geography and Spatial Management, University of Gdańsk, 80-309 Gdańsk, Poland; renata.anisiewicz@ug.edu.pl

\begin{abstract}
The aim of this work is to study the conditions for developing the entrepreneurial ecosystem of regional tourism at the external border of the European Union, in Poland, and its contact points with two non-Union countries (Belarus, Ukraine). The research used a literature review, qualitative and quantitative analyses of the conditions for the development of entrepreneurial ecosystems, interviews with local ecosystem actors and the author's own observations. The eastern border of Poland (formerly with the USSR) created a barrier to the socio-economic development of adjacent regions. Their peripheral nature has allowed preserving their precious nature value and multicultural heritage. Currently, this preservation constitutes grounds for sustainably developing the region's tourism. The primary actors of the tourism-based entrepreneurial ecosystem are local governments, public institutions, non-governmental organisations and entrepreneurs. An impetus for activities thereof was granted by Poland's accession to the EU and its access to Union funds, which has reinforced tourism infrastructure by contributing to the establishment of new tourism enterprises. Furthermore, the development of tourism in the region could also be favoured by the close neighbourhood of as many as two other countries; however, and unfortunately, the border is still a barrier. Apart from the lack of infrastructure allowing borders crossings, political instability in neighbouring countriesmade explicitly visible at the border with Belarus in 2021—threatens border-driven tourism by restricting tourism entrepreneurship, especially in those activities based on the access to the border.
\end{abstract}

Keywords: entrepreneurial ecosystem; border tourism; tri-border area; external border of the European Union; Poland-Belarus-Ukraine borderline area

\section{Introduction}

Border areas constitute special places for developing tourism [1,2]. In the past, the presence of borders determined the peripheral nature of regions there situated. Border protection considerations have influenced the poor development of economic activity, low employment rates and even limited access for persons without permanent residence [3]; they have also hindered or prevented tourism development. A change in the functioning of border processes was initiated in Europe, in the 1950s, and, together with the development of European integration, contributed to opening border regions [4]. Initially, these processes took place in Western Europe, along with political and economic transformations that began at the turn of the 1980s and 1990s, covering Central and Eastern Europe countries.

Tourism became an opportunity for the sustainable development of regions previously determined as peripheral for being situated at borders [5,6]. Due to the poor economic use of many of those regions (a lack of industry, less developed transport infrastructure than in other regions), often resulting from military border protection, precious natural value has been preserved therein [7]. The uniqueness of, at least, some border regions also owes to the richness of their multicultural heritages, having been shaped, for ages, by neighbouring representatives of various nationalities, cultures and religions [2]. 
The most advanced process of borders' disappearance as barriers to socio-economic development concerns Western Europe and, to a lesser degree, other European countries [3]. Borders, here, were also affected by the European integration, in particular, which introduced, in 2007, the possibility of freely crossing borders within the framework of the Schengen Area, with the reservation that not all Union states joined this area and that a few joinees are not EU Member States [8]. The advantages of the accession to the European Union and/or Schengen Area primarily concern the border areas of countries located inside these territories. The circumstances of regions at the periphery of the EU, where the external, strictly protected border of this organisation is situated, are different.

Border locations are especially predisposed to the sustainable development of tourism, especially those with areas of contact with three states, situated in so-called tri-border areas. Such locations, with favourable conditions, can generate development synergy [9]. In the territory of the European Union, especially, the conditions of socio-economic development are specific, including tourism in the tri-border areas of countries located at an external border with two non-Union countries that do not belong to the Schengen area. A group of seven such tri-borders is represented by the tri-border area Poland-Belarus-Ukraine. Apart from a few studies $[9,10]$, it has not been the subject of detailed research, especially in the context of developing entrepreneurial ecosystems.

The aim of this article is to analyse the conditions for the development and functioning of entrepreneurial tourism ecosystems in the context of the external borders of the European Union, in the area of Poland's contact with two countries outside the Union, Belarus and Ukraine. The analysis of this subject matter requires answering the following questions:

- What are the conditions for tourism's development in the region located at the external border of the European Union?

- What are the conditions for development of the entrepreneurial ecosystem in tourism at the external border of the European Union?

- Which actors shape the entrepreneurial ecosystem in tourism at the external border of the European Union?

- How does the presence of the external border of the European Union influence the development of the entrepreneurial ecosystem in tourism?

\section{Scientific Background}

\subsection{Entrepreneurial Ecosystem}

Stimulating socioeconomic development is inseparably linked with the issue of entrepreneurship. The European Commission defines entrepreneurship as "an individual's ability to turn ideas into action. It includes: creativity, innovation and risk taking, ability to plan and manage projects in order to achieve objectives" [11]. Development of entrepreneurship is decided not only by the idea and work of individual entrepreneurs, but also by the entire business environment that creates the supporting network, referred to as the ecosystem.

The issue of the ecosystem in business was first described by Dubini in 1989 [12]. While characterising the activity of family companies in the surrounding of a strong business infrastructure, funds for investment supporting entrepreneurship culture and public policy supporting development of new enterprises, Dubini used the term "environment".

The concept of the "ecosystem" was introduced by Moore in 1993 [13]. He concluded that achieving success in business requires a set of resources, such as: capital, partners, suppliers and customers. They create a network of cooperation where companies can compete and cooperate in the process of developing innovative products and services.

The entrepreneurial ecosystem has been defined many times. A simplified definition was proposed by Stam and Spigel [14], who concluded that this is a set of individual actors and factors coordinated in a manner allowing productive activity in a given area. This group was defined in broader terms by Mason and Brown, who, apart from entrepreneurs, also enumerate organisations, institutions and processes combining formally and informally in order to connect, act as an intermediary and supervise the local entrepreneurship 
environment [15]. The definition from Isenberg is also often quoted. According to this author, the ecosystem is "a set of network institutions aimed at supporting an entrepreneur in undergoing all stages of creating a new enterprise. An entrepreneur is the centre of activity of this network and the measure of its success [16]. According to Isenberg [17], the entrepreneurial ecosystem comprises six domains: policy, finance, culture, support (infrastructure, non-governmental organisations), human resources and market. At the same time, each ecosystem is unique, and it is difficult to copy it to other conditions.

Entrepreneurial ecosystems play a significant role in sustainable development. Sustainable entrepreneurship is associated with ecological entrepreneurship, joining profitorientation with sustainable development. Social and economic issues are taken into account in the context of environmental issues [18,19]. It is postulated to underline the use of local characteristics related to the location, quality of natural environment and functions played by this area in the framework of sustainable entrepreneurship [20]. This aspect of entrepreneurship is of special significance in the border areas, which are characterised with preserved, unmodified natural value.

In the last 30 years an increase in tourist traffic has been observed globally. It reflects changes in the set of conditions, the most important of which comprise the change in the nature of performed work (from physical to service) and an increase in the amount of free time and material wealth. Moreover, they cause changes in the nature of tourism from mass passive to individual or group active [21]. Furthermore, directions of tourist traffic have been extended, which resulted from, among other things, changes in the function of international borders from non-transmissive or poorly transmissive to transmissive $[2,9,22]$, as well as development of transport [23,24], especially air [25].

In this context, the development of entrepreneurship in tourism gains a special significance. Insofar as studies on entrepreneurial ecosystems have a rich literature [26,27], the subject matter of contextual entrepreneurial ecosystems' factors in tourism used to be a less popular field of research. In the context of the available works [28-32], the lack of studies concerning the functioning of entrepreneurial ecosystems in tourism in border areas is noticed. The significant of tourism therein has increased in recent decades, especially in Europe. This was caused by the political-economic transformation in Central and Eastern Europe, as well as the European integration processes occurring throughout the whole region. These contributed to changes in the functions of borders drawn in various ways (weakening or strengthening of a barrier's function), in various border areas. They affect the possibilities of development and the functioning of entrepreneurial ecosystems in these regions.

\subsection{Border Areas as Tourism Development Terrains}

The first works on tourism at border areas were written in the 1970s. The foundations include a publication by Matznetter, in which he distinguishes three types of regions located at borders in the context of tourism development: an area without tourist attractions near the border, a tourist area on the one side of the border and a tourist area spreading on both sides of the border [33]. The impact of tourism on changes in the functions of borders has been described in detail by Timothy $[1,2,34]$. Tourism issues at Polish border areas have been discussed in detail by Więckowski [9].

The attractiveness, to tourists, of areas located at borders can be decided by natural and cultural values. In many cases these terrains constitute poorly economically developed areas, which allows the preservation of non-modified and non-degraded environmental components, such as watercourses and water reservoirs, marshes and moors and forest complexes. Therefore, sustainable forms of tourism are preferred at border areas, which, in the case of conducting tourist activity, will allow guaranteeing long-term preservation of their natural values [35].

Moreover, border areas are also places of coexistence, usually for many generations, of representatives of various nationalities, cultures and religions. Their heritages, if preserved, 
create unique multicultural mosaics, visible in the landscape created by architectural, sacral and secular buildings, rites, language, habits, etc. [36].

The specific character of border areas comprises the presence of a country's borderthe element of space not encountered inside its territory. Various elements of former and current border infrastructure may be interesting for a tourist [37]. These are old border castles, currently unused border passages, former or current markings of borders (a border post, information boards), protective facilities (e.g., fences, entanglements etc.), vantage points and museums. A tourist attraction may also be areas or facilities cut with a border e.g., the city of Cieszyn (Poland-the Czech Republic) or the municipality of Baarle (the Netherlands-Belgium). The distinctness and, thus, the tourist attractiveness of border areas may also be decided by specific rules of residence in these areas, often related to the limited access thereto or even the complete inaccessibility of zones closely adjacent to the border line [9].

The development of tourism in border areas is determined by the nature of the border at which they are located. Depending on this formal-legal or infrastructural transmission, border tourism (on one side of the border) and cross-border tourism are distinguished [9]. Cross-border tourism is related to the possibility of crossing the border by tourists, which is enabled by legal regulations, as well as the existence of infrastructure necessary for such crossing. Developing tourist traffic favours tourism management in both neighbouring countries [33].

In border areas, irrespective of the possibilities of crossing the border, various types of tourist traffic can develop, e.g., recreational, cognitive, religious and environmental tourism [4]. Shopping tourism is characteristic of cross-border tourism and absent in the case of border tourism; it is the most often studied form of cross-border tourism [38-42]. Shopping tourism is related to the possibility of shopping in the neighbouring country or using services there, e.g., catering or health care. The drive for its development usually consists in the difference of prices of various goods and services, as well as a slightly different assortment of quality in neighbouring countries [9].

Since border areas are often poorly urbanised and cover rural areas, development of agritourism may constitute the element developing tourism therein. It is defined as a form of relaxation in rural areas of an agricultural nature, with accommodation and recreation activity related to a farm or the surroundings [43]. Agritourism, constituting a form of alternative tourism, covers a decidedly smaller scale of tourist traffic than the forms of mass tourism [44]. Due to its limited invasiveness, it is preferred as a form of sustainable tourism in terrains that are valuable in terms of nature, which often occur in border areas.

Tri-border areas are special border areas that are the place of contact for the borders of three countries. They accumulate in the close neighbourhoods of tourist value of three different countries [7], and the point of contact between borders constitutes a unique place, of a borderline that can, itself, be a tourist destination [45]. The locations of regions near a tri-border area generate possibilities for the development of tourism and the establishment of cross-border tourist spaces [4]. The attractiveness to tourists of the space around a tri-border area owe to the variety resulting from three countries being available to a small area. Such places are comprised of various languages, cultures, religions, laws, currencies, cuisines and working hours of trade and services [4]. A tri-border area, even if of a peripheral nature, can become a meeting and tourist management centre. When clearly marked (a sign, a pole) it can also become a symbol of neighbour cooperation [4]. One of the oldest places of this type is the tri-border of Belgium-Germany-the Netherlands, marked with a stone pillar and flags as early as in 1926 [3].

At the beginning of the 20s of the 21st century there were approx. 170 tri-border areas in the world [4]. As of 2021 the European Union is comprised of 27 states with 41 tri-border areas. The locations of some are inside the territory of the EU and some at external borders, which determines various conditions for the development of surrounding areas, including tourist activity, primarily related to the possibility of crossing borders. An important role is played by the inclusion of the European states in the Schengen Area, in the territory 
of which free movement of persons, goods and capital is possible. Since not all Union states belong to the Schengen Area, and, simultaneously, some members thereof do not belong to the EU (Switzerland, Norway, Liechtenstein), tri-border areas can be divided into several groups.

In principle, the 12 tri-border areas located at the borders of countries inside the EU should be distinguished from those at the external borders of the EU-29. Among the tri-border areas at the external borders of the EU, contact points of borders of a Union state with one Union state and one non-Union country (19), as well as the tri-border areas of a Union state and two non-Union countries (10) are distinguished.

Tri-border areas at the internal borders of the European Union concern, in majority, countries in the Schengen Area, which means freedom of movement between the area of the involved countries within such a tri-border area. Restrictions are only in place at the tri-border area of Hungary-Slovenia-Croatia, since Croatia does not belong to the Schengen Area.

In the group of countries with access to the external borders of the European Union, the situation depends on the accession to the Schengen Area, and also upon the non-Union countries. The greatest difficulties in the movement of persons concern the combination of Union countries that belong to the Schengen Area, Union countries outside this area and non-Union countries. There are 13 such tri-border areas. Among them, seven are tri-border areas with two non-Union countries outside the Schengen Area, whereas three tri-border areas neighbour Union states belonging to this area, and four neighbour with Union states outside the Schengen Area.

\section{Research Area}

\subsection{Delimitation}

Our research area covers the tri-border area of Poland (a country belonging to the European Union and the Schengen Area), Belarus and Ukraine (non-Union countries). The border drawn between them, on the Bug River, is the former border between Poland and the USSR as determined after the Second World War [46]. As of its creation in 1945, this border has acted as a strong barrier, separating the territories of these two countries, although Poland fell under the zone of the USSR's influence [47]. The non-transmissibility of the border strongly affected the peripheral nature of border areas, here, determining their limited possibilities of socio-economic development after the Second World War [48]. Despite the changes that have occurred in Central and Eastern Europe as a result of politicaleconomic transformation, which began at the turn of the 80s and 90s of the 20th century, the border in this area continues to significantly affect the development possibilities of adjacent countries.

While delimiting the area of research, administrative units at the lowest level (NTS 5) situated at the borderlands in the tri-border area were taken into account (Figure 1). Here, the influence of its borders is the most explicit. On the Polish side, four municipalities comprise the border, Włodawa poviat, in Lublin voivodeship; the city of Włodawa; and 3 rural municipalities, Hanna, Włodawa and Wola Uhruska. On the Belarusian side, the border lies against three selsoviets in the Brest region and oblast, Znamenka, Domachevo and Tomashovka. On the Ukrainian side, the border abuts the Shatsk district in the Kovel region of the Volyn oblast. Our analysis of the area's entrepreneurial ecosystem issues, in terms of tourism, has been conducted for Polish part of the border area, belonging to the European Union. 


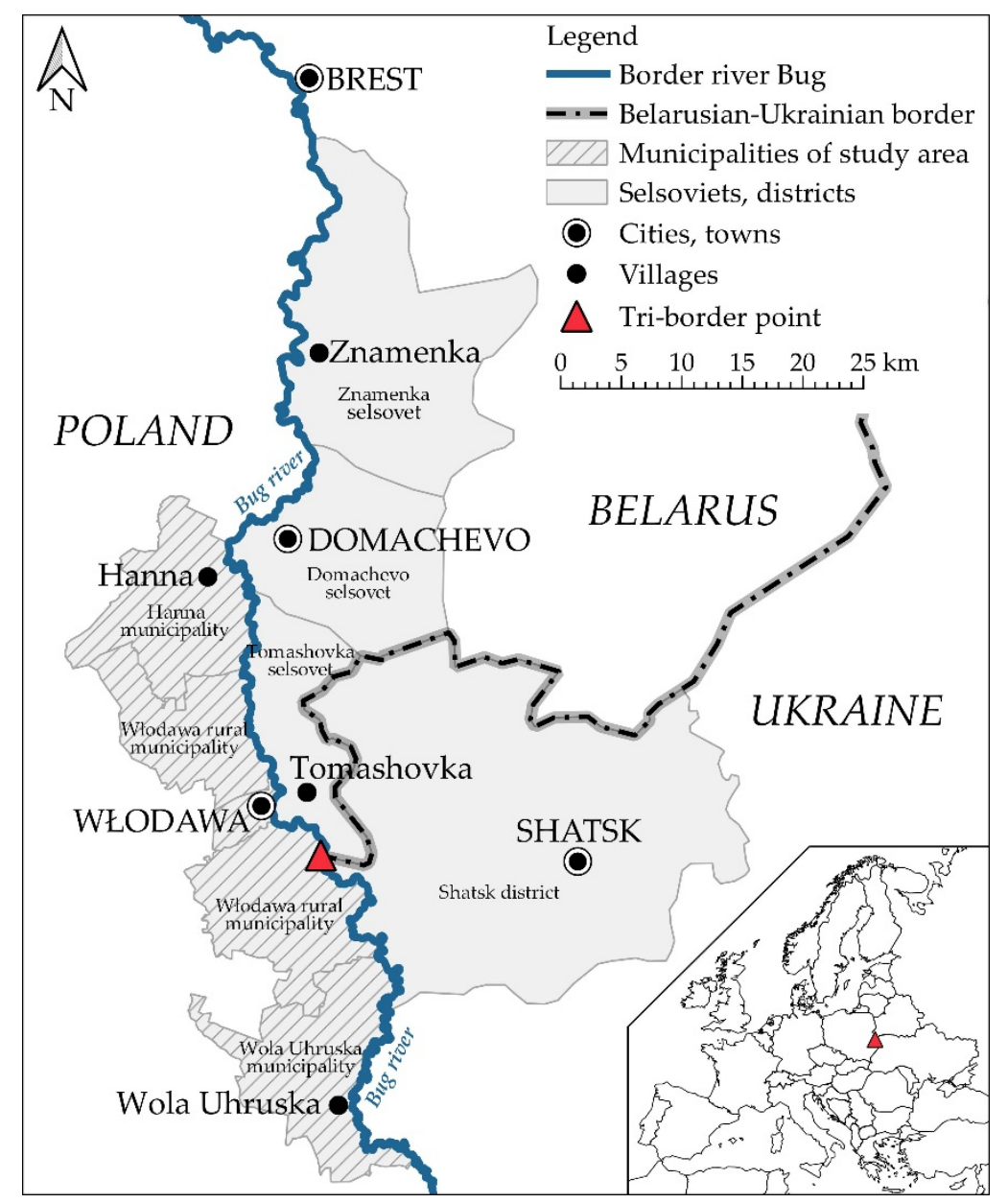

Figure 1. The study area [by author].

\subsection{Tourism Characteristics}

The area surrounding the tri-border point Poland-Belarus-Ukraine has numerous unmodified precious natural value as a result of human activity. In physical-geographic terms, it covers the macroregion of Western Polesie, in Poland called Polesie Lubelskie, in Ukraine-Volynskoye Polesie, in Belarus-Pribuzhskoye Polesie [49].

The studied area is located in the Bug River basin where the border between Poland on the left riverbank, and Belarus and Ukraine on the right riverbank is drawn. Bug is the largest unregulated European river with numerous habitats of fauna and flora. The natural, unmodified landscape and natural value of the Bug River Valley constitute potential for the development of recreational tourism, including canoeing and fishing.

The landscape of terrains adjacent to the Bug River Valley in each of the three countries is dominated by forest and lakeland areas. The most valuable have been covered by legal protection. On the Polish side, in closest proximity to the border, is the Sobibór Landscape Park. The majority of the park is covered by forests intertwined with moors and mid-forest lakes. Forests serve for recreation by allowing nature tourism and benefiting from the undergrowth resources. Moreover, the lakes of the Łęczyńsko-Włodawskie Lakeland are valuable for tourism. The most favourable tourist resources belong to Białe Lake, located approx. $7 \mathrm{~km}$ from the border. It features a relatively large area (106 ha) and depth $(33 \mathrm{~m})$, sandy shores with a beach, a hard, sandy bottom, clear water and surrounding forests [50]. These conditions and its accessibility have contributed to the development of tourist infrastructure in the adjacent village, Okuninka; it is one of the most important holiday resorts in Lublin voivodeship.

The most valuable area of the Ukrainian part of the borderland, in terms of nature, includes the Shatsk National Natural Park, with pine forests, moors and the lakes of 
the Shatsk Lakeland. They are very important for the development of tourism, there; they dominate in size over lakes in the Polish and Belarusian part of the border area. From among over 20 lakes, the largest lake in Ukraine, Svityaz (2620 ha), is distinguished (Figure 2). It has influenced tourist infrastructure and the development of the reservoir's recreational role. Shallower lakes, such as Pulemets and Pisochne, are used in a similar manner [51].

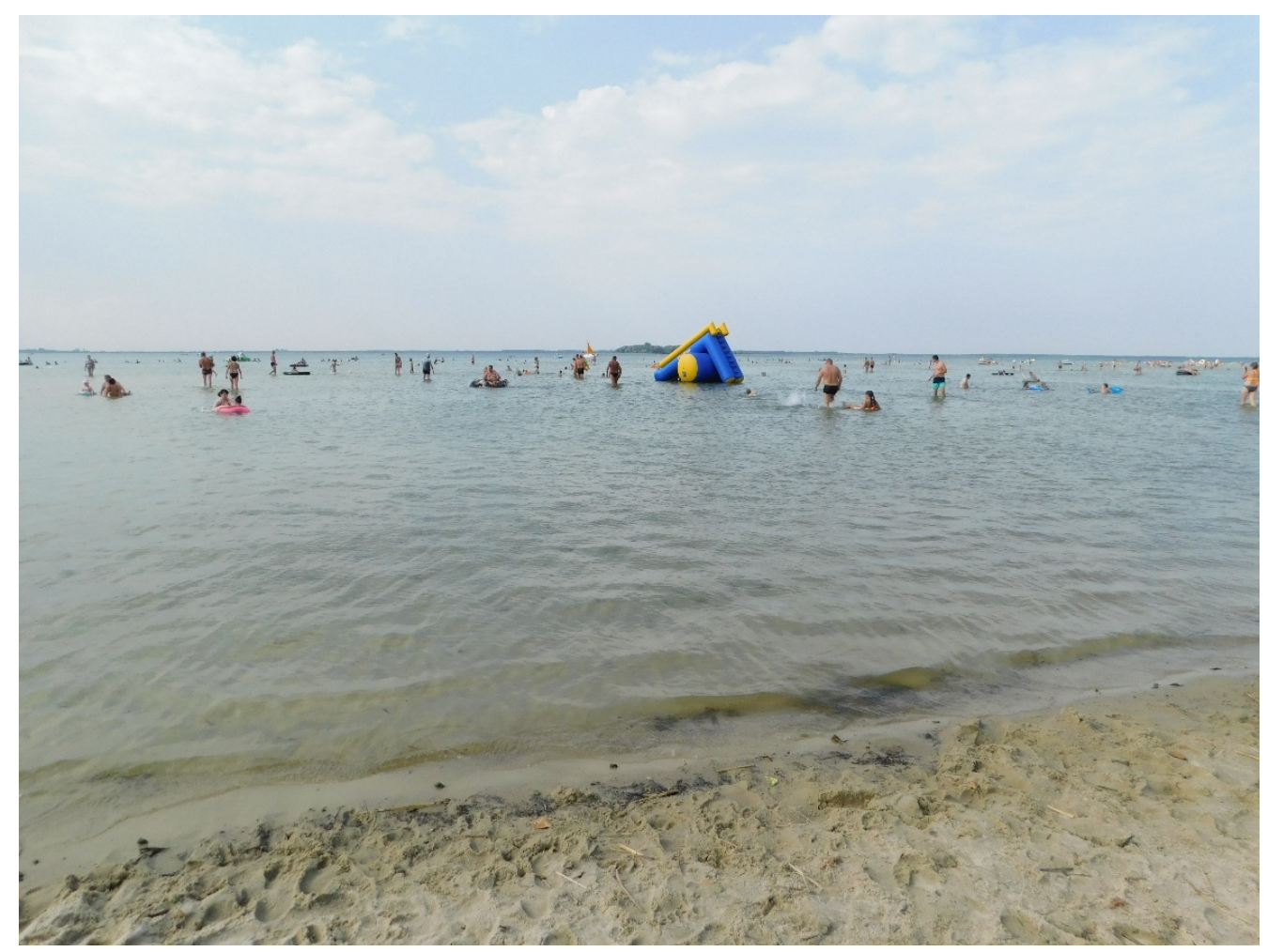

Figure 2. Svityaz Lake [by author].

The most valuable elements of the natural environment of the Belarusian part of the border area include the Bug River Valley and the "Pribuzhskoye Polesie" reserve area, established close to the tri-border point [52]. The majority of the area is covered by forests. They are accompanied by moors and naturally small water reservoirs. The tourist significance is mainly attributed to the Beloye and Rogoznyanskoye lakes. The tourist base has developed primarily at Beloye Lake.

The natural value of the Poland-Belarus-Ukraine tri-border area potentiates of the development of recreational tourism related to the access to inland waters (baths, water sports, fishing), as well as forests and other areas valuable in terms of nature (tracking, cycling, horseback riding, nature tourism like birdwatching, etc.).

The Polish-Belarusian-Ukrainian border area has been, for many centuries, the area of the Polish, Ruthenian and Jewish nationalities' mutual cultural penetration. Today, traces of their heritage constitute the main cultural values of the region [10].

The main city of the region is Włodawa, in Poland, and the city located nearest the tri-border point. The development of Włodawa was influenced by Polish, Ruthenian and Jewish people. Three cultures' heritages have been documented by a baroque Roman Catholic Church a with monastery and a set of three synagogues—currently the Synagogue Museum Complex (Figure 3), as well as classicist Orthodox Church. A unique architectural monument in the region is an 18th century group of former stalls, called the quadrangle, occupying the central part of the market [10]. 


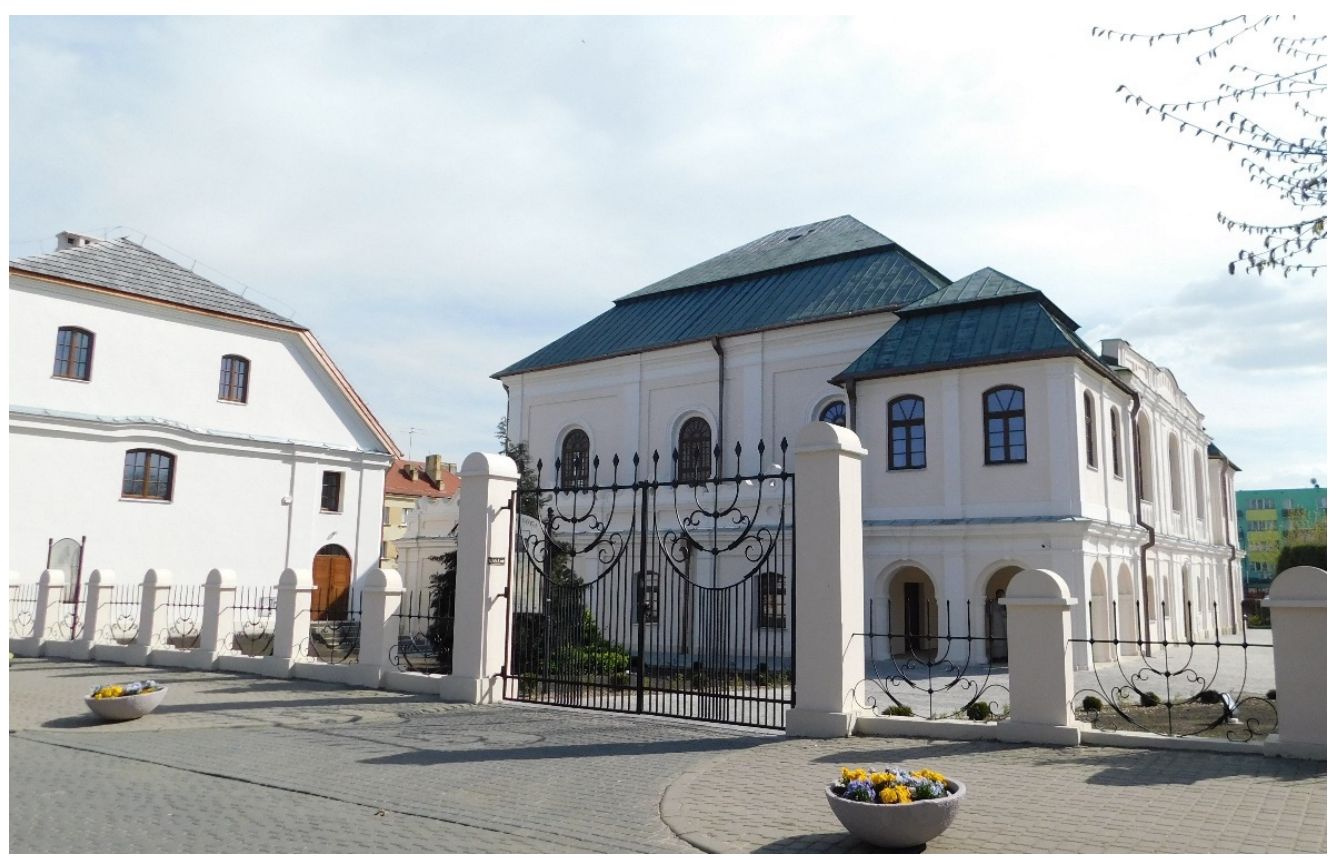

Figure 3. Synagogue Museum Complex in Włodawa [by author].

Antique temples of various denominations from the 17th-19th centuries are also located elsewhere in this border area. The most interesting include Roman Catholic Churches in Uhrusk, Orchówek, Różanka and Hanna, as well as the Orthodox Church in Uhrusk. Moreover, examples of traditional wooden, rural residential constructions remain in various places.

A special historical value of the Polish part of the border area is the former German extermination camp for Jews in Sobibór that operated from 1942-1943. Here, Germans murdered approx. 180 thousand Jews from Poland and other countries. After a successful prisoner uprising, the camp was liquidated by Germans and a forest was planted there. As a result of recent archaeological work the place was developed anew and artefacts collected therefrom have been displayed in the Museum and Memorial Site in Sobibór (Figure 4).

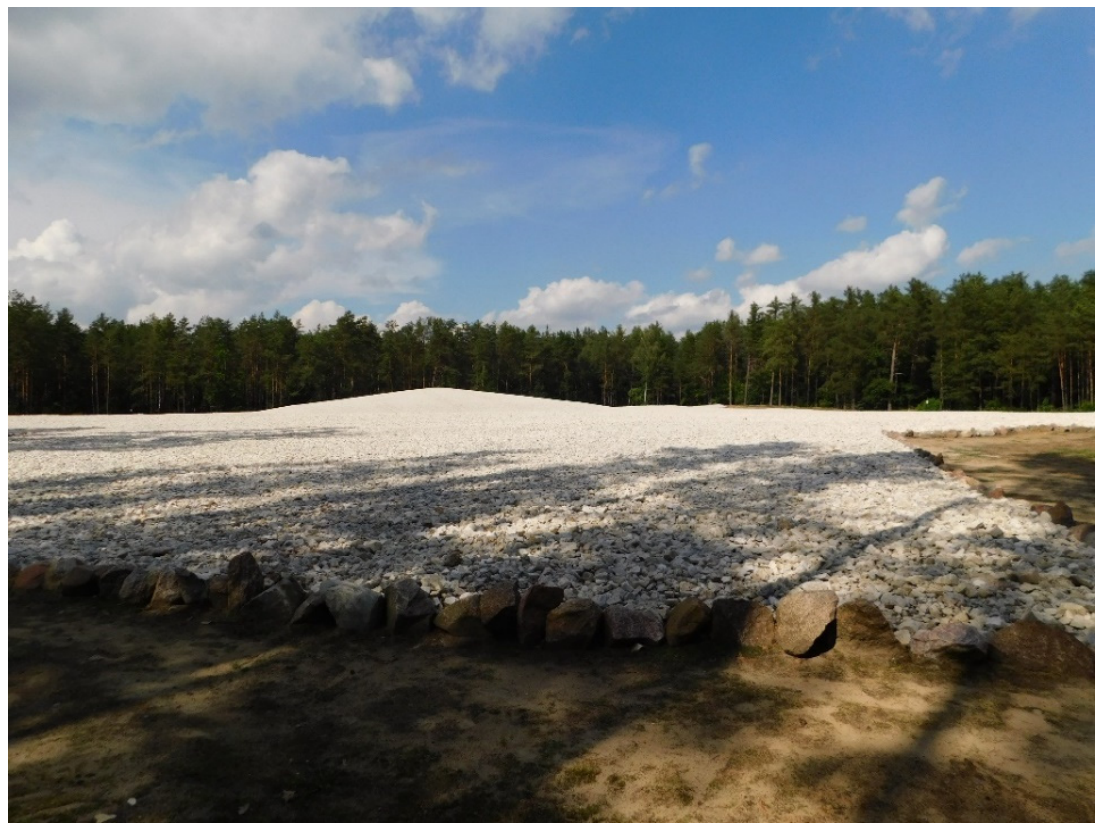

Figure 4. Clearings grave in the Museum and Memorial Site in Sobibór [by author]. 
The material culture monuments of the Belarusian part of the tri-border area include the traditional, wooden residential constructions from the 19th-20th centuries in various locations, and, in bigger settlements, there are also ancient temples so constructed-for example, Domachevo, the wooden Orthodox Church from the mid-19th century, and Medno's Orthodox Church from the 18th century.

A stay in the village Tomashovka, situated in the most south-western part of Belarus, could be a regional tourist attraction; it contains a large cemetery where soldiers from the first World War lie, and, unique in Belarus, the Museum of Aeronautics (Figure 5). Tourists, here, are also served by the catering and accommodation infrastructure and a sports and recreation complex, developed at the beginning of the 21 st century.

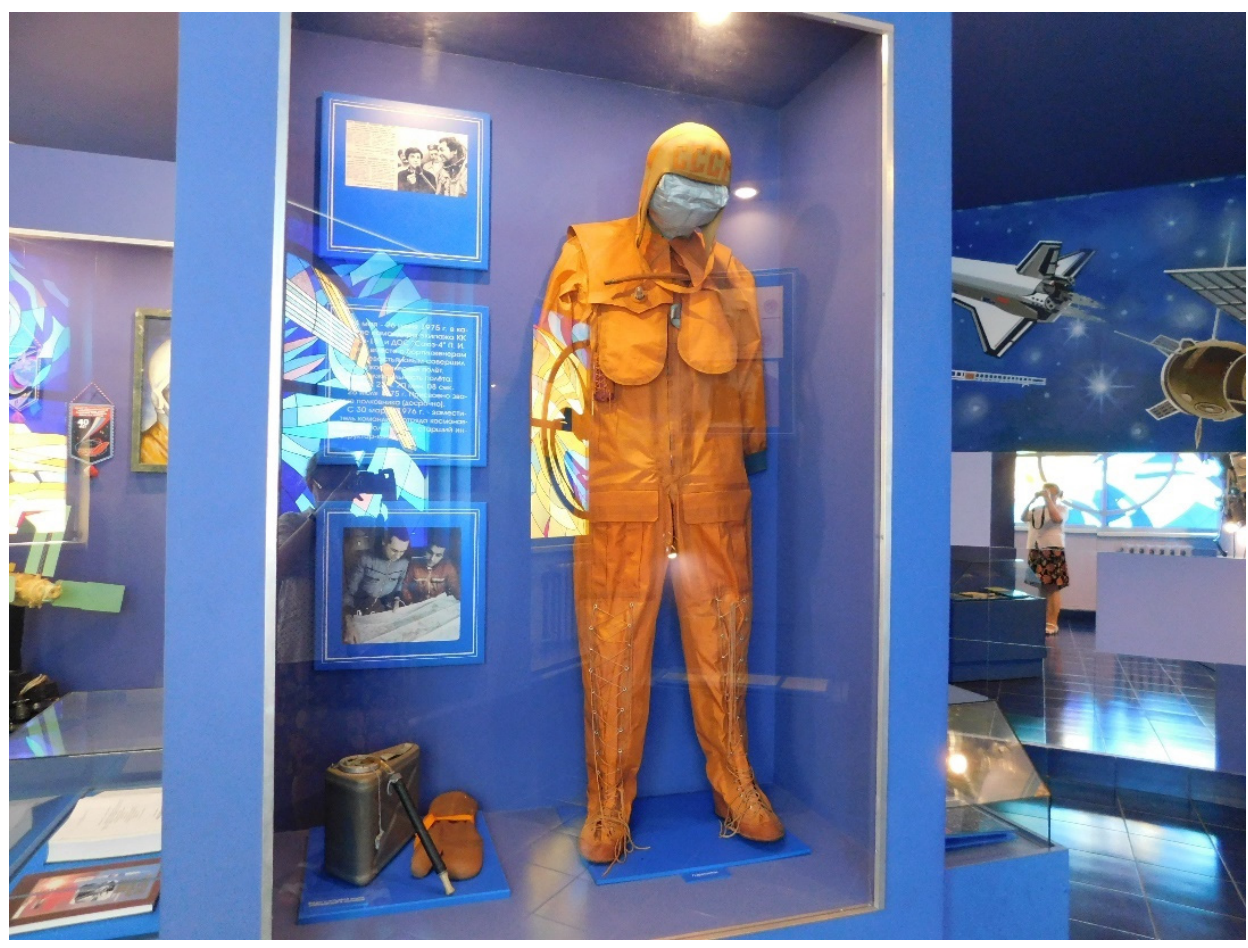

Figure 5. Museum of Aeronautics in Tomashovka [by author].

The tourism value of the Belarusian part of the tri-border area is enhanced by Brest's tourist offerings. Admittedly, the largest city of the Brest oblast is located over $70 \mathrm{~km}$ north of the tri-border area; however, one of only two border crossings allowing access from Poland to the Belarusian tri-border area is there located. The main tourist value of the city is the Brest Fortress, established in the 19th century at the Bug River. The city's construction is characterised by a mosaic of architectural styles into premises that were built as early as the end of the 19th century. Furthermore, Brest has five museums and other cultural and sports facilities.

The Ukrainian part of the studied borderland has a more modest assortment of cultural value. It mainly includes ancient, wooden locations situated in picturesque spots at lakes e.g., in villages such as Svityaz, Pulmo and Ostrov. The only city of the region, Shatsk, resembles a holiday resort with preserved antique Polesie houses. Moreover, antique Orthodox Churches, usually from the 19th century, are located in the regional settlements.

The value connecting the Polish-Belarusian-Ukrainian borderline is the tri-border point (Figure 6). For Poland, it is the only of its six tri-border areas located by the river. The tri-border area is located in the rural municipality of Włodawa, in the proximity of the village Orchówek, which is accessible to tourists from the Polish side. Unfortunately, it is not possible from the Belarusian and Ukrainian sides, a consequence of the these countries' border regime forbidding citizens from accessing the border line, even where it follows a river. 


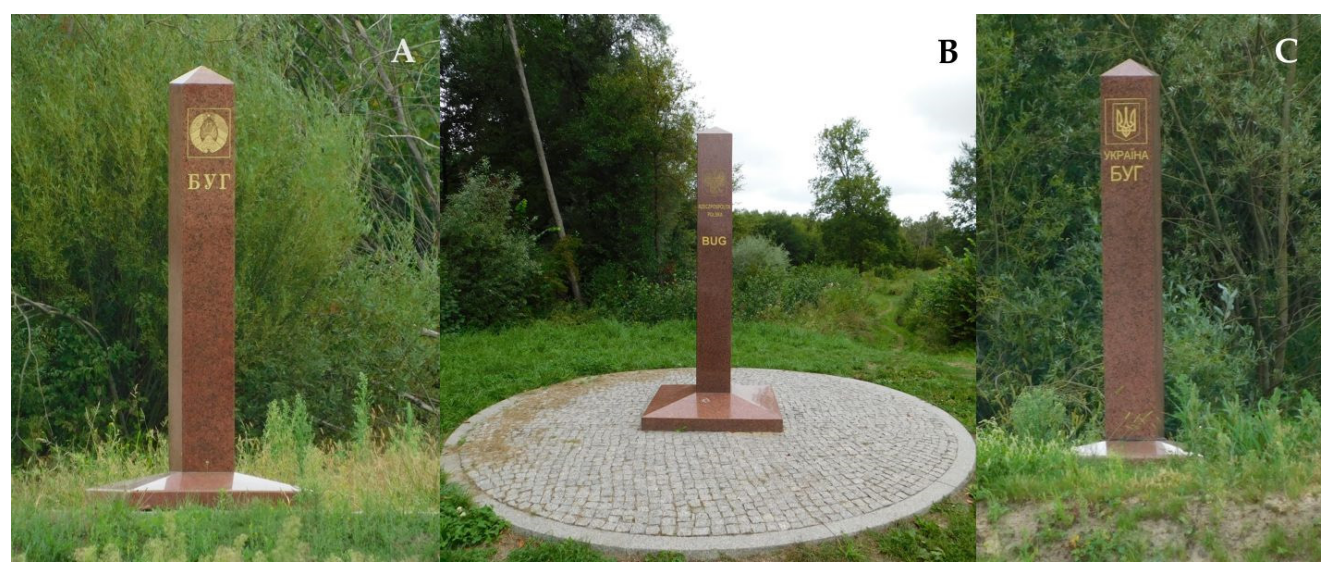

Figure 6. Poles at the tri-border point of Belarus (A), Poland (B) and Ukraine (C) [by author].

\section{Materials and Methods}

The research materials used in this article were collected from various sources. It has been prepared with the use of various research methods. The theoretical component was drawn from a literature study of tourism and borders and border areas, as well as entrepreneurship in tourism.

Information on the tourism development conditions at the Polish-Belarusian-Ukrainian border area near the tri-border point was sourced from the available scientific literature, websites of local governments for regions covered and analysis and terrain observations thereof. The author participated in a study trip to the Belarusian and Ukrainian parts of the border area in 2019, and the collected information was the subject of qualitative analysis.

The analysis of the conditions for the development of an entrepreneurial ecosystem in tourism also included statistical data available on the websites of the National Statistical Offices of Poland, Belarus and Ukraine, as well as studies of the local government units, both regionally (Włodawa poviat, Brest region) and locally (four municipalities in Poland and the Shatsk district). This statistical material was the subject of qualitative and quantitative analyses.

The information on the entities constituting the Polish entrepreneurial ecosystem in the tri-border area was obtained from interviews conducted in 2021 with representatives of the Włodawa Municipality Office competent in the scope of tourism, as well as with the Director of the Synagogue Museum Complex in Włodawa. Furthermore, the websites of these entities and unpublished materials obtained at the office were further sources of knowledge. Moreover, the author, who is personally related to the studied area, used her own many years of observations of changes in the tourist management, development of entrepreneurship and tourist traffic in the Polish part of the tri-border area. The collected research materials were subjected to critical assessment and qualitative analysis.

\section{Results}

\subsection{Borders and the Development of Tourism at the Polish-Belarusian-Ukrainian Border Area}

The tourism characteristics of the region situated at the border are determined by the capacity of crossing it, in formal-legal and infrastructural terms. After Poland's accession to the European Union in 2004, the eastern border of the country became the external border of this organisation. It resulted in a tightening of the border by the introduction of obligate visas for citizens of neighbouring countries. Poland's accession to the Schengen Area in 2007 deepened this obligation [53].

The visa barrier at the Polish-Ukrainian border has been gradually mitigated for both parties. Since 2017, when the visa obligation for Ukrainians arriving in Poland for tourist purposes was abolished, it can be stated that this barrier has disappeared.

The situation at the Polish-Belarusian border, where both parties are bound by visa obligations, is different. In order to encourage tourist traffic in its border areas, as of 
2015, Belarus began introducing the possibility of visa-free entry into Belarus for tourist purposes. Initially, it concerned only the Białowieża Forest; as of 2016, the city of Grodno and the Augustów Canal were included, and as of 1 January 2018, the tourist-recreation zone "Brest" has also been included. This zone covers, among others, the city of Brest and the Brest region. Tourist visa-free movement in Belarus is available to the citizens of 76 countries, including those of the EU. The period of stay, initially 5 , days was extended to 10 days. Belarusians still need visas in order to enter the EU [10].

The introduced facilities became an important step in the direction of tourism's development at the Polish-Belarusian-Ukrainian border area, especially in cross-border terms, as they extended the offerings of available tourist attractions for visitors of the borderland region in Poland with the possibility of a trip outside the external border of the European Union. Along with restrictions related to the coronavirus pandemic, at the beginning of 2020 these facilities were limited.

Aggravating relations between Poland and Belarus, after the latter country's presidential elections in August 2020, significantly affected tourist's possibility of crossing the Polish-Belarusian border visa-free. Admittedly, such visa-free movement has not been formally ended, however, in practice it has ceased to exist. The escalation of tension in Polish-Belarusian relations after the EU introduced sanctions against the regime of the Belarusian authorities in 2021 resulted in a migration crisis at this section of the EU's external border that may result in further withholding of visa-free tourism and thus a reintroduction of the border as a functional barrier to tourism's development.

The possibilities for tourism development in the area surrounding the tri-border point of Poland, Belarus and Ukraine also significantly depend on the conditions of the infrastructure at border crossings, which is very poorly developed in this area. The basic issue consists of the lack of a border crossing from Poland to either Belarus or Ukraine near the tri-border area; Włodawa poviat is the only border poviat in Poland without a border crossing. The nearest road crossing to Belarus is Sławatycze-Domachevo, situated approx. $30 \mathrm{~km}$ north of the capital city of the poviat-Włodawa. Road and railway crossings to Ukraine Dorohusk-Yahodyn are located even further (over $50 \mathrm{~km}$ to the south). Admittedly, this does not close the access to neighbouring countries; however, it significantly hinders the development of cross-border tourism in this area [53].

The basic obstacle for the establishment of a crossing in Włodawa poviat results from the nature of the border, which, at this section, runs along the Bug River, necessitating the expense of constructing a bridge. Unfortunately, the road and railway bridges on the Bug River in Włodawa, destroyed during the 2nd World War, have not been re-built, owing to the nature of the then-binding border between Poland and the USSR, which was supposed to tightly separate, rather than connect, the neighbouring countries [54]. Measures undertaken by local authorities in order to build a bridge after the change of the Polish political system and the break-up of the USSR, at the beginning of the 1990s, have not generated the expected results.

A possible positive impact of a new border crossing on the development of crossborder tourism around the Poland-Belarus-Ukraine tri-border area may be proven by the growing interest of tourists in a temporary pontoon bridge for pedestrian and bicycle traffic, built on the Bug River during the so-called Good Neighbourhood Days (Figure 7). This cross-border event, lasting several days, was organised over 2010-2019 by Włodawa poviat and Wola Uhruska municipal authorities, together with the Ukrainian Shatsk region, in the village of Zbereże, at the border with Ukraine. Its idea was to promote the construction of a crossing connecting the Polish Łęczyńsko-Włodawskie Lakeland with the Ukrainian Shatsk Lakeland. Over a 3-5-day event, the bridge was crossed by up to several dozen thousands of people [10]. Construction of the bridge, in connection with the possible introduction of visa-free crossing of the Belarusian-Ukrainian border at the extant road crossing in Tomashovka-Pulemets (so far, unavailable for Poles without visas), would open opportunities for the development of tourism in the whole region surrounding the tri-border area. 


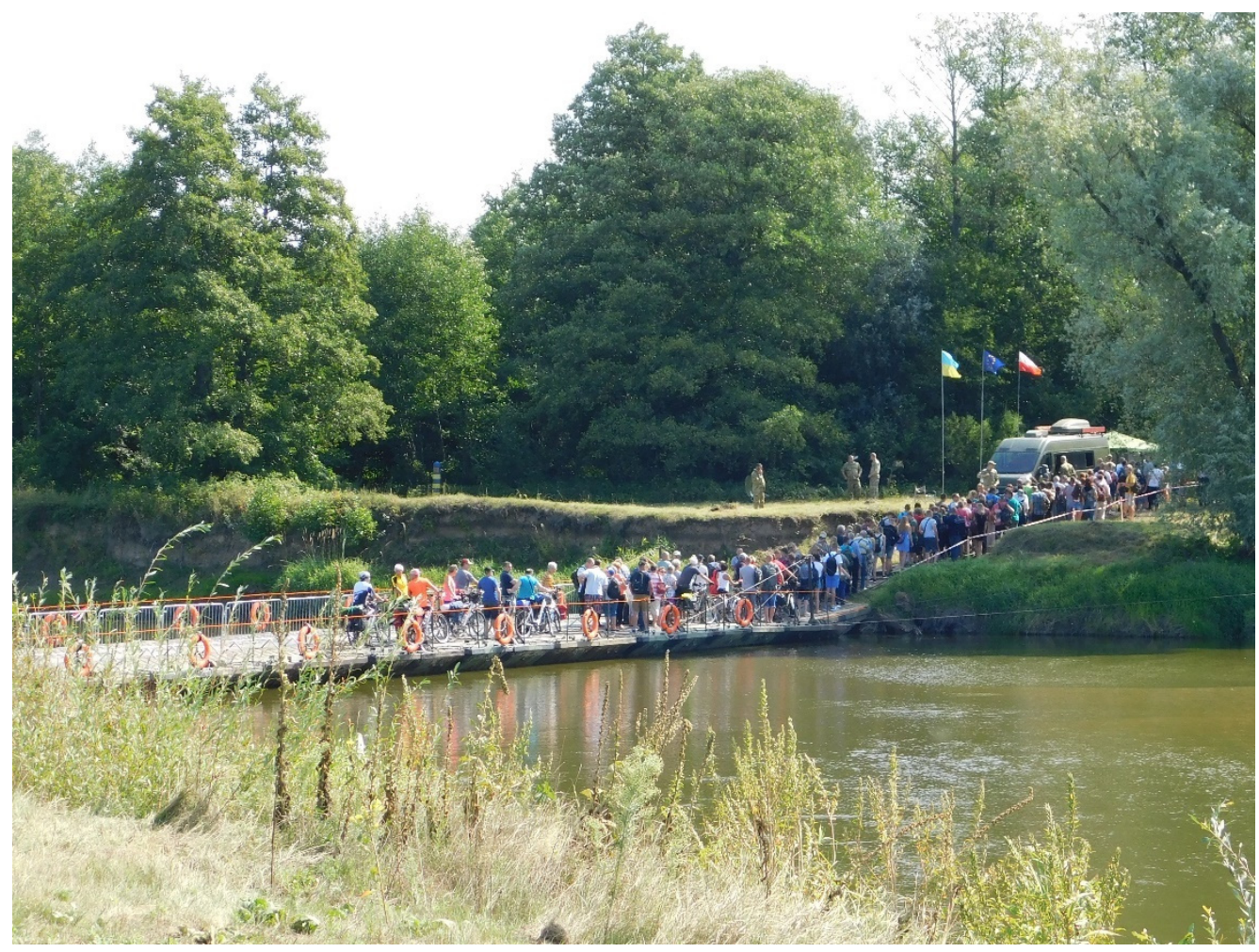

Figure 7. Tourists on the temporary bridge over the Bug River during the Good Neighbourhood Days 2019 [by author].

5.2. Conditions for the Development of an Entrepreneurship Ecosystem in the Polish Part of the Tri-Border Area

\subsubsection{Demographic Conditions}

The area surrounding the tri-border point of Poland, Belarus and Ukraine in 2020 was inhabited by approx. 52.5 thousand people (Table 1). Half of the population inhabit the Polish side (49\%), approx. 30\% the Ukrainian side and approx. 20\% the Belarusian [55-57]. The whole area occupies approx. $1930 \mathrm{~km}^{2}$, of which the Shatsk district in Ukraine covers approx. $40 \%$, and the administrative units of the Polish and Belarusian parts occupy $30 \%$ of the area, each.

Table 1. Population and population density of the tri-border area of Poland-Belarus-Ukraine in 2020.

\begin{tabular}{cccccc}
\hline Administrative Units & $\begin{array}{c}\text { Total } \\
\text { Population }\end{array}$ & Cities/Towns & Villages & $\begin{array}{c}\text { \% In } \\
\text { Cities/Towns }\end{array}$ & $\begin{array}{c}\text { Population } \\
\text { per } \mathbf{1} \mathbf{~ k m}^{\mathbf{2}}\end{array}$ \\
\hline Poland-municipalities in total & 25,546 & 12,915 & 12,631 & $50.6 \%$ & 46 \\
The city of Włodawa & 12,915 & 12,915 & 0 & 2791 & 20 \\
Hanna & 2791 & 0 & 6023 & 3817 & 25 \\
The village of Włodawa & 6023 & 0 & $\mathbf{9 0 4 4}$ & $\mathbf{1 2 . 1 \%}$ & $\mathbf{1 7}$ \\
Wola Uhruska & 3817 & 0 & & 15 \\
Belarus-selsoviets in total & $\mathbf{1 0 , 2 9 1}$ & $\mathbf{1 2 4 7}$ & 0 & & 17 \\
Znamienka & 5280 & 1247 & 2325 & $\mathbf{3 1 . 7 \%}$ & 23 \\
Domachevo & 2686 & 0 & $\mathbf{1 1 , 3 6 4}$ & $\mathbf{2 2}$ \\
Tomashovka & 2325 & $\mathbf{5 2 7 0}$ & &
\end{tabular}

The analysed border area is characterised by small population, which is confirmed by the low values of average population density therefrom, which do not exceed 25 persons per $1 \mathrm{~km}^{2}$. The city of Włodawa-the largest settlement unit of the whole tri-border area, 
which, as a city, concentrates almost one fourth of the region's population, is an exception, with a population density exceeding 700 people per $1 \mathrm{~km}^{2}$.

Low population is related to the poor development of the settlement network, which is dominated by rural settlements. In total, on the Polish side of the area surrounding the tri-border area, there are 44 of them. Small- or medium-sized villages of rarely even several thousand inhabitants are predominant, affecting the low level of urbanisation in the studied area; only $51 \%$ of population is urban (Table 1 ).

The low population characterizing region reflects its peripheral situation in the Polish scope. It consists of a large share of forests, marsh and moor terrains, and of lakes. In the past (the 19th-20th centuries), socio-economic development was hindered by the lack of significant mineral resources and unfavourable conditions for agriculture, which, in turn, determined the poor development of transport infrastructure. After the Second World War, the socioeconomic life of the whole region was also significantly affected by the Polish-Russian border. The borderland location, for strategic defence reasons, did not favour economic activity. These factors hindered the development of the settlement network, contributing, rather, to stagnation and then to demographic regression [53].

The studied borderline area is characterised by a decline in population, beset by both a negative population growth rate and a negative migration balance [10]. This, in turn, affects the age distribution of the population, which indicates demographic aging (Table 2). In the group of people of non-working age, seniors prevail, and a smaller share belongs to children and youth. Approximately $60 \%$ of the population is of working age, which represents the active human resources. This negative trend poses a threat to the development of entrepreneurship in the region.

Table 2. Age distribution of the population of the border area of Poland in 2020.

\begin{tabular}{ccccc}
\hline Administrative Units & Total Population & Pre-Working Age & Working Age & Post-Working Age \\
\hline Municipalities in total & 25,546 & $17.1 \%$ & $59.1 \%$ & $23.8 \%$ \\
Włodawa City & 12,915 & $17.3 \%$ & $57.3 \%$ & $25.4 \%$ \\
Hanna & 2791 & $14.9 \%$ & $61.3 \%$ & $23.8 \%$ \\
Rural Włodawa & 6023 & $19.1 \%$ & $60.4 \%$ & $20.5 \%$ \\
Wola Uhruska & 3817 & $14.8 \%$ & $61.9 \%$ & $23.3 \%$ \\
\hline
\end{tabular}

Low urbanisation and historic-economic conditions have resulted in the majority of inhabitants of the Polish tri-border area earning their livings from agriculture. The labour market is supplemented by small production plants, usually in the food industry, as well as services providing for facilities located in larger settlement centres. The studied part of the region is characterised by unemployment rates that are relatively higher than other administrative units of Lublin voivodeship. The situation in the region may be improved by the development of sustainable tourism, generating new workplaces or supplementing income generated from agriculture with agritourism.

\subsubsection{Transport Availability}

A factor that significantly affects the development of entrepreneurship, including tourism, is the region's transport availability, as it permanently shapes the foundations of socio-economic development [58]. Transport availability depends on the level of development and quality of infrastructure, especially of roads and railways.

The neighbourhood of the tri-border area of Poland-Belarus-Ukraine is characteristically peripheral to the transport networks of these countries; no main transport routes of the countries run through this area. Their transport networks are based only on regional and local roads [10].

The main transport axis of the Polish part of the studied border area is the Voivodeship Road no. 816 running along the Bug River, at the eastern border of Poland. It connects border locations and provides for the possibility of accessing border crossings with Ukraine in the south (Dorohusk-Yahodyn) and Belarus in the north (Sławatycze-Domachevo and 
Terespol-Brest). These crossings are located outside Włodawa poviat. The border area can also be accessed by National Road no. 82, connecting Włodawa, through ŁęczyńskoWłodawskie Lakeland, with Lublin, as do Voivodeship Roads no. 812 (Chełm-WłodawaBiała Podlaska) and no. 818 (Parczew-Włodawa). The area's road network is supplemented by poviat and municipal roads. The region is, therefore, accessible from other parts of the country. However, the quality of these roads is of lower rank, and while many have been renovated in recent years, improvement is still required in some sections.

The areas surrounding the tri-border of Poland-Belarus-Ukraine do not have crossborder railway connections. However, a railway line, Brest-Chełm, built in 1887 and separated by a lack of a bridge on the Bug River from the Belarusian (Brest-Włodawa) and Polish (Włodawa-Chełm) parts, otherwise runs through the Belarus and Poland through the Bug River [54]. The Belarusian section of the railway line is of crucial importance for transport service in the border region. Passenger and cargo trains run regularly [59]. Currently, the Chełm-Włodawa railway line is of small transport significance; as of 2012, passenger transport runs only on weekends in the summer season. The location of Włodawa station, approx. $4 \mathrm{~km}$ from the city centre, constitutes a hindrance for the functioning of the railway connection. A chance to revive the railway in the Polish part of the borderline area would be its modernisation and the extension of the line into the city centre of Włodawa, as well as to the neighbouring village of Okuninka, at Białe Lake. The efficient operation of the Chełm-Włodawa railway line, since it runs through borderline areas that are attractive in terms of their nature and landscapes-and also in close proximity (approx. $2 \mathrm{~km}$ ) of the tri-border area-could be an additional factor in the development of border-area tourism. A Chełm-Włodawa line modernisation project was included in the government modernisation programme of the local and regional railway infrastructure "Railway+", the implementation of which is planned to last until 2028 [60].

\subsection{Entrepreneurial Ecosystem in the Polish Part of the Tri-Border Area}

\subsubsection{Local Governments}

A fundamental role in creating conditions favouring the development of entrepreneurship is played by local government authorities; mainly, the units of lower levels (municipalities and poviat), as well as voivodeship authorities. In the studied area, these are four municipal governments (the city of Włodawa, the municipality of Włodawa, Hanna and Wola Uhruska) and the poviat office in Włodawa. Of the various types of activities they undertake and which stimulate the development of the region (e.g., promotional activities, reliefs for investors), the creation of infrastructure that permanently encourages the further development of various forms of activity is of fundamental significance. Apart from the transport infrastructure necessary for many areas of economy, the existence of attractive tourist management in attracting visitors to a given region's tourism is of crucial importance [61].

Measurable benefits for the development of various types of infrastructure were demonstrated by Poland's accession to the EU in 2004, as were the related possibilities for obtaining funding to implement various projects. Among the measures undertaken in this scope by local governments in the studied area to increase tourists' interest in the region of eastern Poland, a joint initiative of the local governments of five voivodeships located along the whole eastern border of Poland, including Lublin voivodeship, should be detailed. It covered creating a bicycle route, named East of Poland Cycling Trail Green Velo, running, to a large extent, directly along the eastern border of the state [62]. This route was established under the European Regional Development Fund within an operational programme entitled the Development of Eastern Poland 2007-2013. In the studied area, it runs through nine locations. The route was partially placed on less-frequented public roads and partially on developed cycle paths. In the area of the borderland municipalities of Włodawa poviat, eight cyclist service spots, with roofed places for rest, information boards and small supplementary infrastructure were created. The Green Velo route promotes the development of bicycle tourism without interfering in the natural environmental 
resources, fitting the trend of sustainable tourism development. Despite the lack of mass adoption of this type of tourism, Green Velo significantly contributed to the increase in the number of tourists visiting Poland's borderline area locations, which is confirmed by the representatives of local government authorities and other entities providing services to the tourist traffic, as well as the author's own observations.

Moreover, the local governments of the studied municipalities and Włodawa poviat have undertaken other measures in the scope of construction or modernisation of the local tourist infrastructure. Given the relatively small incomes of the local governments of this borderland region, such would not be possible without the support of European funding. Obtaining funds significantly intensified in the second decade of the 21st century. Examples of projects resulting in increased interest in the region and implemented within Regional Operational Programmes of Lublin Voivodeship for the years 2007-2013 and 2014-2020 have been compiled in Table 3.

Table 3. Infrastructural projects supporting tourism in borderland municipalities of Włodawa poviat.

\begin{tabular}{|c|c|c|c|}
\hline Project Name & Beneficiary & Value in PLN & $\begin{array}{l}\text { EU Co-Financing } \\
\text { in PLN }\end{array}$ \\
\hline \multicolumn{4}{|c|}{ Regional Operational Programme of Lublin Voivodeship for the years 2007-2013 } \\
\hline $\begin{array}{c}\text { Improvement of tourist accessibility of Włodawa-the city of three borders } \\
\text { and three cultures }\end{array}$ & Urban municipality of Włodawa & $2,362,060.55$ & $1,650,575.04$ \\
\hline $\begin{array}{l}\text { Promotional programme for cultural and tourist values of Włodawa-the } \\
\text { city of three borders and three cultures }\end{array}$ & Urban municipality of Włodawa & $1,976,619.94$ & $1,382,774.96$ \\
\hline Tourist and recreational management of Włodawa Municipality & Rural municipality of Włodawa & $1,949,088.14$ & $1,364,361.69$ \\
\hline The Bug River Valley-Endless Possibilities & Wola Uhruska Municipality & $3,737,362.80$ & $2,512,897.95$ \\
\hline $\begin{array}{c}\text { Improvement of tourist accessibility of St. Louis Church in Włodawa } \\
\text { situated at the Three Cultures Route }\end{array}$ & St. Louis Roman Catholic Church Parish & $3,672,469.39$ & $2,569,036.38$ \\
\hline $\begin{array}{c}\text { Improvement of communication in the ancient centre of Włodawa-the City } \\
\text { of Three Cultures }\end{array}$ & Urban municipality of Włodawa & $4,013,769.03$ & $1,635,894.36$ \\
\hline \multicolumn{4}{|c|}{ Regional Operational Programme of Lublin Voivodeship for the years 2014-2020 } \\
\hline The Bug River wooden architecture monuments in Hanna municipality & Hanna Municipality & $8,345,608.35$ & $5,562,639.94$ \\
\hline Revitalisation of Włodawa & Urban municipality of Włodawa & $18,487,807.40$ & $12,796,834.88$ \\
\hline Renovation of ancient Orthodox Churches in Uhrusk, Chełm and Dubienka & Orthodox Church parish in Chełm & $7,082,023.25$ & $5,420,326.03$ \\
\hline Increasing accessibility of the ancient synagogue complex in Włodawa & Synagogue Museum Complex & $4,972,571.26$ & $3,419,130.17$ \\
\hline $\begin{array}{c}\text { Modernisation of the ancient synagogue complex in Włodawa-Great and } \\
\text { Small Synagogue }\end{array}$ & Synagogue Museum Complex & $3,998,621.60$ & $2,768,043.37$ \\
\hline $\begin{array}{l}\text { Eastern cultural heritage of Łẹczyńsko-Włodawskie Lakeland: revitalisation } \\
\text { of ancient Orthodox Churches in Włodawa and Sosnowica }\end{array}$ & Orthodox Church parish in Włodawa & $3,972,078.29$ & $2,583,109.33$ \\
\hline $\begin{array}{c}\text { Modernization of the ancient Synagogue Complex in Włodawa-Kahal } \\
\text { Home and green areas }\end{array}$ & Synagogue Museum Complex & $1,450,225.24$ & $1,010,135.32$ \\
\hline Włodawa Tourist Route- the Bug River Promenade & Urban municipality of Włodawa & $1,253,319.99$ & $744,054.06$ \\
\hline
\end{tabular}

The joint project "The Bug River Valley-Endless Possibilities" was of significant importance for the improvement of the conditions of tourism development in all municipalities situated at the borderland. It covered, among others, the determination of tourist routes in this region and the construction of bicycle stops, summerhouses, sheds, observation towers, piers from which to launch kayaks and information boards. Thus, it enriched the infrastructure of the Green Velo route.

Furthermore, the renovations of routes, ancient sacral facilities and green areas was also performed in this infrastructural improvement. Among the new investments those developed in 2019 in the village of Hanna should be listed, which included the Religious and Antique Centre, around the renovated, ancient, wooden church (Figure 8), housing a museum and an art gallery, as well as the Dialogue Centre (a meeting place for cultures and religions). Another investment was the walking promenade at the Włodawka River (a tributary of the Bug River) in Włodawa, which entered service in 2020.

From among the smaller investments from recent years that contribute to the increase of the tourist movement in the studied area, the point at which three borders of PolandBelarus-Ukraine connect at the Bug River, in the rural municipality of Włodawa, should be mentioned. The development of this land began in 2004, when, as a result of preaccession funds, a path leading thereto was developed. Nevertheless, the connection point was not clearly marked in the area, which, considering the insufficient care for the condition of the path, did not facilitate reaching the destination. Only in 2017 did the authorities of Włodawa municipality undertake decisive measures to render the place 
accessible to tourists. The condition of the path was improved and marked, and, at the place near the river where the tri-border point connects, was placed a granite pole with a sign reading "The Bug River" (Figure 6). A summerhouse with a camping spot is also located nearby. Further activities are planned in 20201, aimed at facilitating tourists' access to this unique facility.

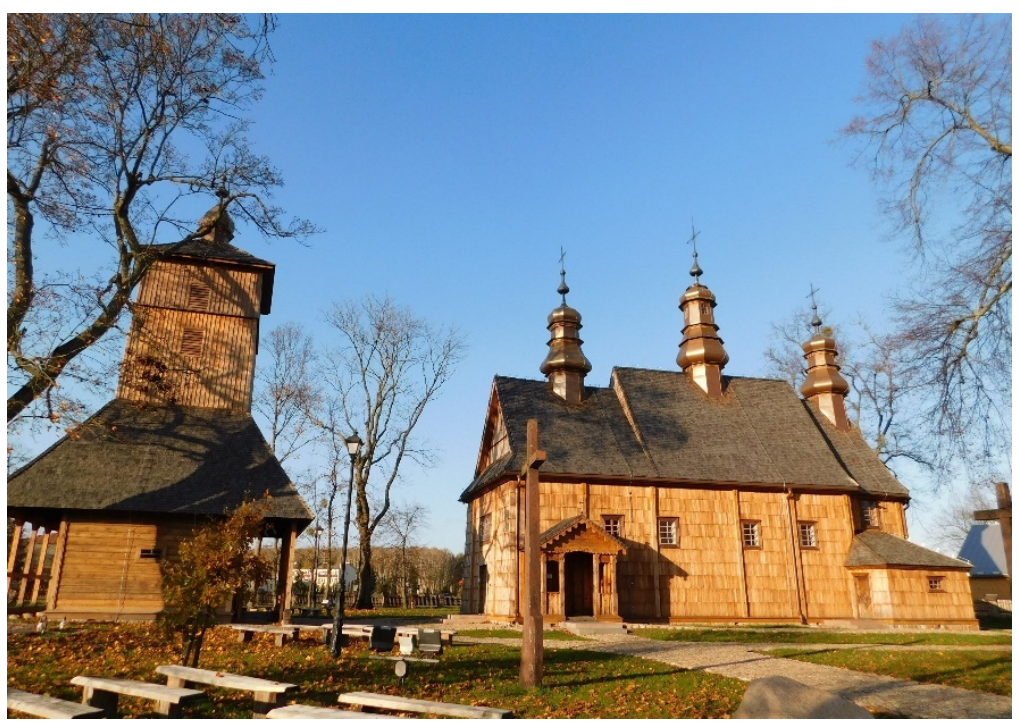

Figure 8. Baroque wooden church in the Religious and Antique Centre in Hanna [by author].

\subsubsection{Public Institutions}

Another group of entities of the local entrepreneurial ecosystem, the activity of which increases the region's tourist attractiveness and thus may create demand for tourist services and give an impulse for entrepreneurship development, is comprised of public institutions, including those governed by local governments. In the studied borderland area this role is played, in particular, by two museum facilities, the Synagogue Museum Complex in Włodawa and the Museum and Memorial Site in Sobibór.

The Synagogue Museum Complex is Włodawa poviat's local government facility. Its seat is the complex of three synagogues, unique on the global scale, and the source of the multicultural heritage of the region [63]. The museum actively engages in measures toward the region's development. Among the permanent projects of crucial importance for the development of tourist movement, various modernisation works of ancient synagogue buildings - the intensity of which has increased in the second decade of the 21st century, to a large extent due to the obtained Union funds—should be included (Table 3).

The inflow of tourists is also decided by the offerings of attractions organised by the museum. From among the various propositions there addressed to inhabitants and tourists, the most important is the Three Cultures Festival, organised annually since 1995. Its idea is to present the multicultural heritage of the borderline area where Włodawa is located. Various forms of presentation (concerts, theatre performances, exhibitions, fairs) and the participation of creators of, at least, national fame, determine on the increasing popularity of the festival with visitors from Poland and abroad. The three-day event, organised annually in September, attracts several thousand people and generates demand for services provided by local entrepreneurs serving tourist traffic (accommodation, catering, etc.). It is an effective tourism element, simultaneously promoting the tri-border area's values. A great opportunity to develop entities providing tourist services in the city and region may be the entrance of the synagogue complex to the list of UNESCO World Heritage Sites, for which the local government authorities of Włodawa poviat have already applied.

A second public entity whose activity will have a significant impact on the development of tourism at the borderline area is the Museum and Memorial Site in Sobibór, a constituent of the National Museum in Majdanek. It is situated in a former Nazi Germany 
extermination camp for Jews [64]. This new development of the place has contributed significantly to increasing the attractiveness thereof to tourists. Artefacts from the period of the camp's existence were collected during archaeological research recently conducted and are displayed in the newly built museum, opened in autumn of 2020; though, due to the coronavirus pandemic the museum has been open to visitors only since 2021. The facility has raised significant visitor interest; the daily count of visitors in the summer season of 2021 reached a surprising 700 people. A considerable number of visitors were cyclists, touring the Green Velo route. It should be assumed that a similar trend will continue in the future and, perhaps especially after the COVID-19 pandemic ceases to limit international travel, it may even increase due to foreign tourism.

\subsubsection{Non-Governmental Organisations}

Support for local development, among others, by the development of tourism, is also provided by the bottom-up initiatives of local social leaders originating from various contexts. In the studied area, such a role is played by a local action group (LAG), the association "Poleska Dolina Bugu", who are distinctive, in terms of their activities, by comparison with other organisations [65]. They undertake measures to develop rural areas with resources provided by the participation of the European Agricultural Fund for Rural Development. The association was established in 2006 by representatives of three rural municipalities of Włodawa poviat (Włodawa, Hańsk, Wola Uhruska). The number of members has consecutively increased in the intervening years. In 2021 it included seven rural municipalities, including all three from the tri-border area and the rural municipality of Włodawa, which joined the group in 2015. Apart from local government units, in 2020 "Poleska Dolina Bugu" included over 60 entities from the economic sector (entrepreneurs, farmers) and social sector (inhabitants, organisations). Measures undertaken by the association initially consisted in developing the Integrated Rural Development Strategy and then in implementing of set objectives, aimed at the promotion of these areas and the actively inclusion of their inhabitants.

The "Poleska Dolina Bugu" local action group supports projects aimed at the extension of existing economic activities with new forms thereof, establishing new enterprises and diversifying activity in the non-agricultural direction. Many of them are directed at tourism development. Effects of the LAG's support in the scope of the development of entrepreneurship in tourism are also visible in the area of the studied municipalities. Due to funds obtained with the LAG's support in the years 2011-2020, at least seven new accommodation facilities have been established (mainly in the villages of Orchówek and Okuninka), as well as several catering companies. Within the diversification of activity in the non-agricultural direction, six farms from different locations used granted funds to start agritourist activity and another three, which had already operated in this area, extended the scope of offered services. Furthermore, new companies providing recreation services were established, including bicycle rentals, a canoeing organisation and paintball.

Moreover, "Poleska Dolina Bugu" has been obtaining funds for the improvement of the infrastructure used in tourism, which, at a later stage, may translate into inspiring entrepreneurship in tourism and creating new workplaces in this area. Among the projects implemented in the border-area municipalities, the following may be listed, inter alia, the remake of a former organist's home in the village of Różanka to the Tradition Chamber and adaptation of the church tower in Orchówek as avantage point.

Another non-governmental organisation in the entrepreneurial ecosystem of the studied area is the Nadbużańskie Agritourism Association in the village of Wola Uhruska. Since 1995 , it has been actively operating to the benefit of agritourism, preferred in sustainable development. It associates several agritourists farms located at the Bug River site, especially in the municipality of Wola Uhruska. It also includes single farms in other municipalities of the studied border area. 


\subsubsection{Actions of the Entrepreneurial Ecosystem Actors and the Level of Tourist Traffic}

All measures undertaken for the purposes of tourist development by the aforementioned entities of the studied borderline area's entrepreneurial ecosystem have resulted in increasing tourists interest. This is confirmed by the increase in the number of tourists observed in various places of the region in recent decades. It is difficult to precisely determine the level of tourist traffic; this is due, among other things, to the lack of accessibility of the data concerning accommodation in tourist facilities, the actual number of which is also difficult to verify.

The estimated number of tourists staying at the Polish side of the tri-border area may nonetheless be determined by analysing the number of visitors of the Synagogue Museum Complex in Włodawa. Włodawa concentrates facilities attractive to tourists, including the often-visited complex of three synagogues. Therefore, it may be assumed that the number of museum visitors (Figure 9), on the grounds of this institution's data, reflects trends in changes and the level of tourist traffic, at least approximately.

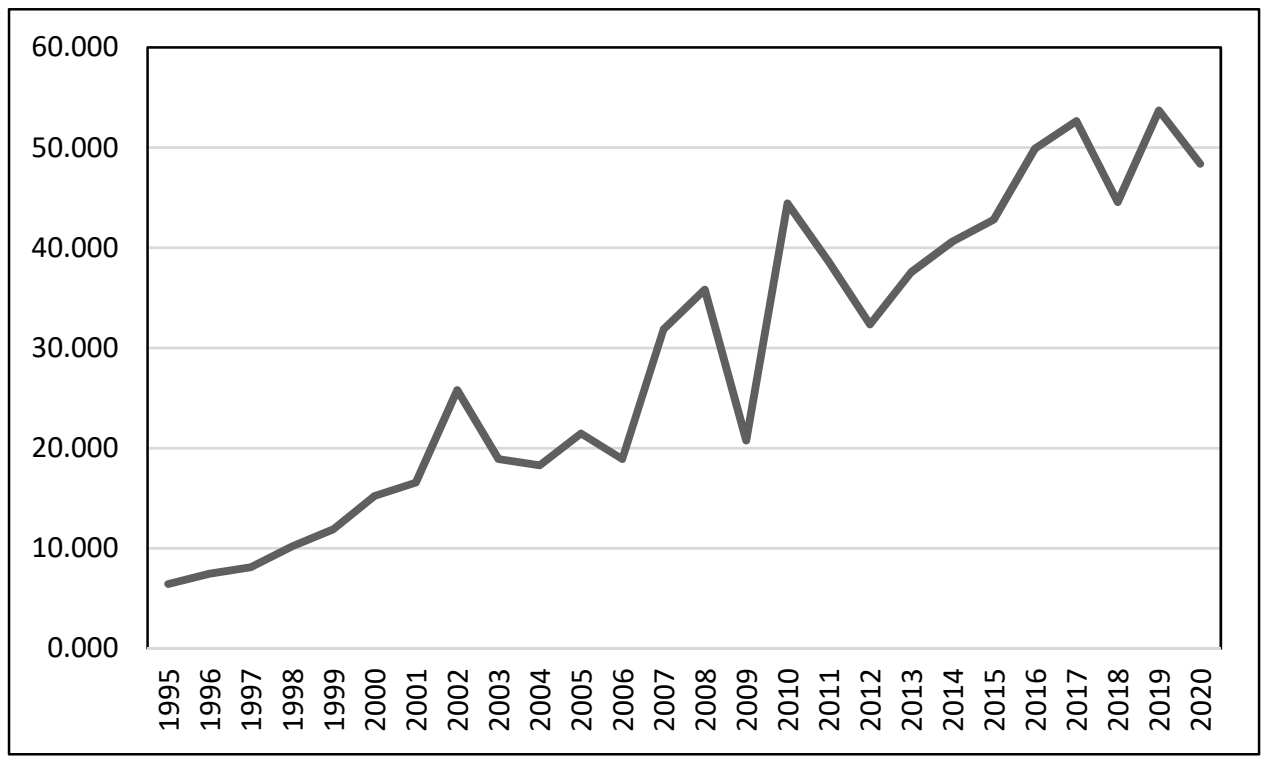

Figure 9. Tourists visiting the Synagogue Museum Complex in Włodawa in the years 1995-2020 (source: unpublished data of the Synagogue Museum Complex in Włodawa).

Data available since 1995 clearly show an upward trend in tourists' interest in the region. Over 25 years (1995-2020) the number of museum visitors has increased approx. 7.5 times. While in the 1990s fewer than 10 thousand people visited annually, in the second decade of the 21st century at least 40 thousand, and even over 50 thousand people have been coming annually. Since not all those coming to the region visit museums, and a large group of tourists come only to rest by the water in the neighbouring village of Okuninka, it should be assumed that the total number of tourists is even higher. This data also reflects the increase in demand for tourist services, which constitutes an area for the development of entrepreneurship in this field.

\subsection{Development of Entrepreneurship in Tourism}

The national upward trend concerning interest in tourism in the 21st century and various measures undertaken by institutions making up the local entrepreneurship ecosystem for the development thereof has resulted in increased demand for tourist services in the Poland-Belarus-Ukraine tri-border area. It contributes to stimulating entrepreneurship in this area, although it is not as dynamic as in other regions of the country. An important driver has been provided by Union funds' co-financing of economic activity.

The activities of persons entering entrepreneurship are mainly demonstrated by the establishment of an accommodation base and, to a lesser extent, catering facilities 
and other types of tourist services. However, such activity is not evenly spread in all municipalities. It is decided by the characteristics of the rural municipality of Włodawa when compared with the three remaining municipalities of this Polish borderland area. Due to the presence of Białe Lake, which is attractive in terms of tourism, this municipality has the most established tourist base in the region, and has been developed since the 1960s. Nevertheless, this base is primarily concentrated in Okuninka and the greatest development thereof is observed here. This is confirmed by the numbers of new accommodation facilities entered into the register kept by the Włodawa Municipality Office over 2000-2019 (Table 4). However, it should be underlined that, in reality, this number is higher, as it is influenced by the lack of an obligation to report this type of activity to municipality offices.

Table 4. Accommodation facilities entered into the register of the rural municipality of Włodawa over 2000-2019.

\begin{tabular}{|c|c|c|c|c|c|c|c|c|}
\hline Years & $\begin{array}{c}\text { Municipal } \\
\text { Facilities in Total }\end{array}$ & Okuninka & Orchówek & Sobibór & Szuminka & Suszno & Żłobek & Korolówka \\
\hline 2000 & 4 & 4 & & & & & & \\
\hline 2001 & 3 & 3 & & & & & & \\
\hline 2002 & - & & & & & & & \\
\hline 2003 & 4 & 4 & & & & & & \\
\hline 2004 & 11 & 10 & 1 & & & & & \\
\hline 2005 & 8 & 7 & & 1 & & & & \\
\hline 2006 & 4 & 4 & & & & & & \\
\hline 2007 & 4 & 2 & 2 & & & & & \\
\hline 2008 & 4 & 2 & 1 & & 1 & & & \\
\hline 2009 & 3 & 3 & & & & & & \\
\hline 2010 & 2 & 1 & & & & 1 & & \\
\hline 2011 & 4 & 2 & & & 1 & & 1 & \\
\hline 2012 & 11 & 10 & 1 & & & & & \\
\hline 2013 & 5 & 4 & 1 & & & & & \\
\hline 2014 & 1 & & & 1 & & & & \\
\hline 2015 & 5 & 2 & 1 & & & 1 & & 1 \\
\hline 2016 & - & & & & & & & \\
\hline 2017 & - & & & & & & & \\
\hline 2018 & 3 & 2 & 1 & & & & & \\
\hline 2019 & 4 & 3 & 1 & & & & & \\
\hline
\end{tabular}

From among all 80 facilities registered over 20 years in the entire municipality, as many as 63 (a majority of which are seasonal) are located in Okuninka. As of 2004, a new accommodation base has also been created in other locations of this municipality, especially in the Bug River's village of Orchówek, neighbouring Okuninka. In the two first decades of the 21st century, nine generally small facilities have been established here, including three agritourist farms. Inhabitants of five other locations in the municipality decided to start agritourist activity. The majority of lodgings (six of eight) were established in locations situated along the Bug River, in Sobibór, Suszno and Szuminka, using their advantageous locations on this border river.

The municipality of Wola Uhruska, in which, as of 1995, i.e., the initial period of agritourism's development in Poland [61], several agritourist lodgings have been established, also focused on the development of its agritourism, using the advantages of the Bug River, along which they are primarily located. A smaller development of the accommodation base has occurred in the municipality of Hanna, where there are now three agritourism locations and several providers of rooms for rent. Changes in the accommodation base have also been observed in the city of Włodawa; however, in this case, the well-developed base in the neighbouring Okuninka is a strong competitor. In the second decade of the 21st century three facilities offering guest rooms with several places each were established. Recently, a tendency to establish small apartments for rent has been visible, and three were established in 2021. 
Entrepreneurship in tourism also includes establishing companies providing other tourist services. Similar to the arrangement of the accommodation base, this area in the studied borderland is concentrated in Okuninka, in the rural municipality of Włodawa. It includes entities operating in the summer season e.g., the rental of water equipment or other vehicles for tourists, which are services typical of seasonal, waterfront locations.

In the 21st century, local entrepreneurs began noticing the potential of environmental elements of the borderline area other than Białe Lake; in particular, the Bug River as it runs along the border line. Consequently, three companies organising canoeing on the river were established in Włodawa municipality. The activity thereof gained popularity among tourists, both local and foreign, who are interested in learning about one of the last non-managed large rivers of Europe. The canoeing offered is extended by the opportunity of camping along the Bug River, next to the infrastructure established for this purpose. As the development of bicycle paths produced impulses to start bicycle rental facilities, other activities facilities have been recently developing, such as horseback riding centres. Small stables offering various services (horseback riding lessons, hippotherapy, etc.) surfaced in the municipality of Hanna (1), the rural municipality of Włodawa (3), the city of Włodawa (1) and Wola Uhruska (1). In 2020 alpaca breeding was established. In the same year, one of the entrepreneurs extended his activity with a cornfield labyrinth and archery. Moreover, tourists can participate in a soap-production workshop in a small manufacturing enterprise established a few years ago.

The enumerated examples indicate blooming entrepreneurship in the scope of tourism in the borderline area, especially in the last twenty years. It has also become increasingly diverse, covering not only the creation of accommodation facilities, but also other facilities attracting tourists. Nevertheless, this process is only at the beginning stage of its development.

One issue facing the entrepreneurship development in the borderline area is the inhabitant's lack of knowledge of and conviction to the possible benefits that may be generated by the aforementioned or similar forms of tourist activity. This especially concerns locations situated outside the main tourism centres of the region (Okuninka, Włodawa), which have at their disposals elements of interesting value, but which are poorly promoted or not promoted at all; this subject constitutes important challenges for the local entrepreneurship ecosystem.

\section{Discussion}

This article is an attempt to analyse the development of the entrepreneurial ecosystem in an area at an early stage of its tourism development, in the context of geographical conditions, particularly, being located at the border of the country and the UE. Debbage [66] has drawn attention to the lack of such contextual research.

The border areas of Poland, Belarus and Ukraine surrounding the tri-border contact point of these countries has, at its disposal, precious resources of natural and cultural value that provide grounds for sustainably developed tourism. The preservation thereof was affected by the poor development of economic activity in this terrain after the Second World War determined the nature of the border between Poland and the USSR (until 1991), which, for strategic reasons, was a strong barrier to international contact. This area accurately represents the border areas indicated by various authors [2,5,9] for the development of sustainable tourism.

Tourism development is a chance for revival, especially of rural areas, the inhabitants of which dominate the studied borderline area. The development of natural, environmentfriendly agritourism is preferred, there. It is favoured by clear air, unmodified landscapes and distance from larger population clusters. These factors, connected by proper infrastructure, represent a recreational base, and an active one, as postulated by Miszczuk [53], for tourists from urban areas that, currently, is not fully used. While taking into consideration the needs of this segment of tourists, it should be assumed that these facilities could function and generate income all year round. Moreover, in analysing the currently offered 
services, it seems that the scope thereof could be extended to the production of handicraft products invocative of local traditions, as well as other regional products (e.g., cheese, honey, etc.). Catering facilities offering local cuisine are also missing, especially in the Bug River's locations.

The boosting of tourist movement in the Polish part of the borderline area in the 21st century has also been significantly influenced by Poland's accession to the EU in 2004. New opportunities, especially the financing of various projects, has allowed beginning the shaping of the entrepreneurial ecosystem in tourism, which is comprised, apart from entrepreneurs, of local governments, public institutions and non-governmental organisations. An important role for creating a climate for entrepreneurship in tourism is also played by measures undertaken by local governments, alone and in cooperation with other institutions. A measurable, permanent effect thereof is the improvement of the existing infrastructural conditions and the development of new infrastructure attracting tourists to the region (e.g., bicycle paths). Actions taken within the framework of the emerging ecosystem increase the chance for developing tourism in the region, as is confirmed by Audretsch's and Belitski's research [67].

An increase in the number of tourists in two first decades of the 21st century has generated bigger demand for services provided by entrepreneurs operating in the tourist industry. A development of the accommodation base, and, to a lesser extent, the catering base, has been observed. Moreover, companies providing tourist services (e.g., organisation of canoeing, horseback riding centres) have been established. The development of entrepreneurship, in this scope, is still not that advanced. However, the progress in this area is clearly visible as compared with the state described by Miszczuk a few years earlier [53].

It is worth paying attention to the gradual activation of tourism's development in other borderline area locations, apart from the well-developed Okuninka at Białe Lake. Their larger share should favour the sustainable development of the region and prevent pressure on the natural environment resulting from the concentration of tourist activity in only one location of the region.

A necessary element of activating other places in the region is improving their transport accessibilities, especially in terms of the condition of local roads. The importance of this factor has been emphasized by various authors [23,24,34,53]. Despite many recent such investments in the study area, some remain in an unsatisfactory condition. A driver of sustainably developing tourism may also be the revitalisation of the Chełm-Włodawa railway line, included in the plans of the government programme Railway+. After a possible partial change in its course, covering the construction of railway up to the village of Okuninka and into the city of Włodawa, low-emission rail transport would take on some of the tourist traffic to Okuninka, focusing, in the summer season, on the main access roads of the region. A revitalised railway would also favour further development of the tourist functions of the adjacent Bug River locations in the Wola Uhruska and Włodawa municipalities. Moreover, the further development of bicycle paths is important for the tourist activity in the region. The examples from already created paths (e.g., within the Green Velo route) indicate their role as a factor stimulating increases in tourist traffic. The success of these activities depends on the efficient functioning of the whole entrepreneurship ecosystem.

A specific factor for the borderline areas' influencing tourism is the border itself. The transmissibility thereof determines the possibility of developing various forms of tourism, including shopping tourism, which is most often associated with a border. The tourist attractiveness of a border area is improved by the close proximity of three countries meeting at such a tri-border area, as in the case of the studied Polish-Belarusian-Ukrainian borderlands. Unfortunately, in the studied example, the border still acts as a barrier to all forms of international contact. Thus, it contributes only to the development of border tourism, and not cross-border tourism, which would increase the tourist attractiveness of the whole tri-border area. The situation, here, is different than in the areas around other tripoints of internal borders with the EU in Poland, as in the Poland-Czech Republic- 
Slovakia tripoint, analysed by Więckowski [4]; the issue is the lack of infrastructure allowing border crossing (i.e., abridge on the Bug River) in the proximity of the tri-border area, exacerbated by formal and legal conditions of crossing borders external to the European Union (especially at the Polish-Belarusian border).

A significant threat is also posed by the unstable geopolitical situation in the region, which may have been felt in the second half of 2021. The migration crisis instigated by the Belarusian side of its border with the European Union resulted in Poland's declaration of a state of emergency in the border area (up to $3 \mathrm{~km}$ from the border) and the limitation of entry therein on 2 September 2021. It has especially affected the tourist industry. Any further restrictions in border protection from the Polish side will have a negative impact on the tourist activity in the border region, especially the activity of entrepreneurs directly benefiting from the advantages of the border.

The border itself is, therefore, an important factor in the development of tourism in border areas. Its presence determines the specificity of the conditions for the development of an entrepreneurship ecosystem in these areas that is absent in other areas, which is confirmed by the considerations of other studies $[31,32,68,69]$.

\section{Conclusions}

The conducted analysis fills, at least partially, the gap in the research of tourism-based entrepreneurial ecosystems in border areas. The information collected during field studies and queries of various sources made possible the identification of the conditions for and actors in developing an entrepreneurial ecosystem in the Polish part of the tri-border point Poland-Belarus-Ukraine, itself part of the EU.

An unquestionable impetus for the development of entrepreneurship in tourism in this previously poorly developed tourist area has been Poland's accession to the EU and subsequent access to funds for developing tourism infrastructure and economic activity in this field. In this context, research identifying the determinants of the development of the entrepreneurial ecosystem in the non-EU Belarusian and Ukrainian parts of this area would be advisable. The compilation of the results of these studies would allow obtaining a comprehensive picture of the determinants of developing the entrepreneurship ecosystem in tourism in such diverse areas surrounding the border tri-point.

Unfortunately, the complicated political situation at the EU's external borders in 2021, especially at the Polish-Belarusian section, may pose a serious threat to the development of tourism in the border area covered by this research, as well as a barrier to further research. Restricting access to this area for non-residents on the Polish side (from September 2021) reflects the still-important role of the border as a condition for the development of tourism's attractiveness to tourists in this border area. Research carried out in areas surrounding other tripoints could significantly increase the knowledge of the role of the border in the development of border-tourism ecosystems.

Author Contributions: The author has read and agreed to the published version of the manuscript.

Funding: This research received no external funding.

Institutional Review Board Statement: Not applicable.

Informed Consent Statement: Not applicable.

Data Availability Statement: Not applicable.

Conflicts of Interest: The author declares no conflict of interest.

\section{References}

1. Timothy, D.J. Political Boundaries and Tourism: Borders as Tourist Attraction. Tour. Manag. 1995, 16, 525-532. [CrossRef]

2. Timothy, D.J. Tourism and Political Boundaries; Routledge Advances in Tourism; Routledge: London, UK, 2001.

3. Kałuski, S. Blizny Historii. Geografia Granic Politycznych Wspótczesnego Świata (History Scars. Geography of the Political Boundaries of the Contemporary World); Wydawnictwo Akademickie Dialog: Warsaw, Poland, 2017. (In Polish) 
4. Więckowski, M. How Border Tripoints Offer Opportunities for Transboundary Tourism Development. Tour. Geogr. 2021. [CrossRef]

5. Gelbman, A.; Timothy, D.J. From Hostile Boundaries to Tourist Attractions. Curr. Issues Tour. 2010, 13, 239-259. [CrossRef]

6. Jóhanesson, G.T.; Huijbens, E.H. Tourism in Times of Crisis: Exploring the Discourse of Tourism Development in Iceland. Curr. Issues Tour. 2010, 13, 419-434. [CrossRef]

7. Kałuski, S. Border Tri-points as Transborder Cooperation Regions in Central and Eastern Europe. In Regional Trans-Border CoOperation in Countries of Central and Eastern Europe-A Balance of Achievements; Geopolitical Studies; Kitowski, J., Ed.; Geopolitical Studies: Warsaw, Poland, 2006; Volume 14, pp. 27-36.

8. Timothy, D.J.; Saarinen, J. Cross-border Cooperation and Tourism in Europe. In Trends in European Tourism Planning and Organization; Costa, C., Panyik, E., Buhalis, D., Eds.; Channel View Publication: Bristol, UK, 2013; pp. 64-74.

9. Więckowski, M. Turystyka na Obszarach Przygranicznych Polski (Tourism in the Border-adjacent Areas of Poland); Polish Academy of Sciences: Warsaw, Poland, 2010. (In Polish)

10. Anisiewicz, R. Condition for Tourist Development in the Tri-border Area of Poland, Belarus and Ukraine. Geogr. Tour. 2019, 7, 51-64. [CrossRef]

11. Official Journal of European Union. Available online: https:/ / eur-lex.europa.eu/eli/reco/2006/962 (accessed on 4 August 2021).

12. Dubini, P. The Influence of Motivations and Environment on Business Startups: Some Hints for Public Policies. J. Bus. Ventur. 1989, 4, 11-26. [CrossRef]

13. Moore, J.F. Predators and Prey: A New Ecology of Competition. Harv. Bus. Rev. 1993, 71, 75-83.

14. Stam, E.; Spigel, B. Entrepreneurial Ecosystems and Regional Policy. In Sage Handbook for Entrepreneurship and Small Business; Blackburn, R., De Clerq, D., Heinonen, J., Wang, Z., Eds.; Sage: London, UK, 2016.

15. Mason, C.; Brown, R. Entrepreneurial Ecosystems and Growth Oriented Entrepreneurship. Final Rep. OECD $2014,30,77-102$.

16. Isenberg, D.J. How to Start an Entrepreneurial Revolution. Harv. Bus. Rev. 2010, 88, 40-50.

17. Isenberg, D.J. The Entrepreneurship Ecosystem Strategy as a New Paradigm for Economic Policy: Principles for Cultivating Entrepreneurship; Institute of International European Affairs: Dublin, Ireland, 2011; pp. 1-13.

18. Allen, J.C.; Malin, S. Green Entrepreneurship: A Method for Managing Natural Resources? Soc. Nat. Resour. Int. J. 2008, 21, 828-844. [CrossRef]

19. Hörish, J. The Role of Sustainable Entrepreneurship in Sustainability Transitions: A Conceptual Synthesis Against the Background of the Multi-level Perspective. Adm. Sci. 2015, 5, 286-300. [CrossRef]

20. Bański, J.; Chmieliński, J.; Czapiewski, K.; Mazur, M.; Szymańska, M.; Wilkin, J. Przedsiębiorczość na Wsi-Współczesne Wyzzania i Koncepcje Rozwoju. (Entrepreneurship in the Countryside-Contemporary Challenges and the Concept of Development); Fundacja na rzecz Rozwoju Polskiego Rolnictwa: Warsaw, Poland, 2015. (In Polish)

21. Panfiluk, E. Problemy Zrównoważonego Rozwoju w Turystyce (Problems of the Sustainable Development of Tourism). Econ. Manag. 2011, 2, 60-72. (In Polish)

22. Sofield, T.H.B. Border Tourism and Border Communities. An Overview. Tour. Geogr. 2006, 8, 102-121. [CrossRef]

23. Lumsdon, L.; Page, S. Tourism and Transport: Issues and Agenda for the New Millennium; Advances in Tourism Research Series; Elsevier: Amsterdam, The Netherlands, 2004.

24. Khadaroo, J.; Seetanah, B. Transport Infrastructure and Tourism Development. Ann. Tour. Dev. 2007, 34, 1021-1032. [CrossRef]

25. Kowalczyk, A. Relacje Zachodzace między Rozwojem Transportu Lotniczego a Rozwojem Turystyki (Relations beetwen the Development of Air Transport and the Development of Tourism). In Wspótczesne Uwarunkowania i Problemy Rozwoju Turystyki (Contemporary Conditions and Problems of Tourism Development); Pawlusiński, R., Ed.; Instytut Geografii i Gospodarki Przestrzennej, Uniwersytet Jagielloński: Cracow, Poland, 2013; pp. 61-72.

26. Solvoll, S.; Alsos, G.; Bulanova, O. Tourism Entrepreneurship-Review and Future Directions. Scand. J. Hosp. Tour. 2015, 15 (Suppl. S1), 120-137. [CrossRef]

27. Koh, K.Y. Tourism Entrepreneurship: People, Places and Processes. Tour. Anal. 2006, 11, 115-131. [CrossRef]

28. Koh, K.Y.; Hatten, T.S. The Tourism Entrepreneur: The Overlooked Player in Tourism Development Studies. Int. J. Hosp. Tour. Adm. 2002, 3, 21-48. [CrossRef]

29. Kline, C.; Hao, H.; Alderman, D.; Kleckley, J.W.; Gray, S. A Spatial Analysis of Tourism Entrepreneurship and the Entrepreneurial Ecosystem in North Carolina, USA. Tour. Plan. Dev. 2014, 11, 305-316. [CrossRef]

30. Bakas, F.E.; Duxbury, N.; Vinagre de Castro, T. Creative Tourism: Catalyzing Artisan Entrepreneur Networks in Rural Portugal. Int. J. Entrep. Behav. Res. 2019, 25, 731-752. [CrossRef]

31. Akbari Samani, N.; Badri, S.A.; Rezvani, M.R. Performance Evaluation of Elements of Rural Tourism Entrepreneurship Ecosystem. Case Study: Teheran Province. J. Rural. Res. 2020, 11, 565-575. (In Persian) [CrossRef]

32. Baloaloa, J. Extent of Influence of Entrepreneurial Ecosystem Elements (E3) on Entrepreneurial and Tourism Activities among Beach Resorts Entrepreneurs in Ilocos Norte. Asian J. Multidiscip. Stud. 2019, 2, 119-127.

33. Matznetter, J. Border and Tourism: Fundamental Relations. In Tourism and Borders: Proceedings of the Meeting of the IGU Working Group - Geography of Tourism and Recreation; Gruber, G., Lamping, H., Eds.; Institute für Wirtschafts-und Sozialgeographie der Johann Wolfgang Goethe Universität: Frankfurt, Germany, 1979; pp. 61-73.

34. Timothy, D.J. Relationships between Tourism and International Boundaries. In Tourism and Borders: Contemporary Issues, Policies and International Research; Wachowiak, H., Ed.; Ashgate Publishing: Aldershot, UK, 2006; pp. 9-18. 
35. Zielińska, A. Fundusze Unijne dla Zrównoważonej Turystyki na Obszarach Natura 2000 (EU Funds for Sustainable Tourism in Natura 2000 Areas). Pr. Nauk. Uniw. Ekon. We Wrocławiu 2008, 2, 114-123.

36. Barwiński, M. Geographical and Sociological Aspects of Borderland-An Outline of Main Issues. Acta Univ. Lodz. Folia Geogr.-Oeconomica 2002, 4, 11-23.

37. Jacobsen, J.K.S. The Making of an Attraction: The Case of North Cape. Ann. Tour. Res. 1997, 24, 341-356. [CrossRef]

38. Timothy, D.J. Shopping Tourism, Retailing and Leisure; Channel View Publications: Clevedon, UK, 2005.

39. Timothy, D.J.; Butler, R.W. Cross-border Shopping: Canada and the United States. In Borders and Border Politics in Globalizing World; Ganster, P., Lorey, D.E., Eds.; SR Books: Lanham, MD, USA, 2005; pp. 285-300.

40. Szytniewski, B.B.; Spierings, B.; van der Velde, M. Socio-cultural Proximity, Daily Life and Shopping Tourism in the Dutch-German Border Region. Tour. Geogr. 2017, 19, 63-77. [CrossRef]

41. Bar-Kołelis, D.; Wendt, J.A. Comparison of Cross-border Shopping Tourism Activities at the Polish and Romanian External Borders of European Union. Geogr. Pol. 2018, 91, 113-125. [CrossRef]

42. Ramsey, D.; Thimm, T.; Hehn, L. Cross-border Shopping Tourism: A Switzerland-Germany Case Study. Eur. J. Tour. Hosp. Recreat. 2019, 9, 3-17. [CrossRef]

43. Drzewiecki, M. Podstawy Agroturystyki (The Basics of Agritourism); Oficyna Wydawnicza OPO: Bydgoszcz, Poland, 2001. (In Polish)

44. Szwichtenberg, A. Turystyka Alternatywna i Ekoturystyka-Nowe Pojęcia w Geografii Turyzmu (Alternative Tourism and Ecotourism-New Concepts in the Geography of Tourism. Turyzm 1993, 3, 51-59. (In Polish) [CrossRef]

45. Studzieniecki, T. Destynacje Transgraniczne w Europie-Identyfikacja, Klasyfikacja i Perspektywy Rozwoju (Cross-border Destinations in Europe-Identification, Classification and Development Perspectives). In Wymiana Doświadczeń i Dobrych Praktyk we Wspótpracy Transgranicznej (Echange of Experiences and Good Practises in Cross-Border Cooperation; Dabrowski, D., Zbucki, Ł., Eds.; Państwowa Szkoła Wyższa im. Papieża Jana Pawła II: Biała Podlaska, Poland, 2020; pp. 18-31.

46. Eberhardt, P. Polska i Jej Granice. Z Historii Polskiej Geografii Politycznej (Poland and Its Borders. From the History of Polish Political Geography; Wydawnictwo UMCS: Lublin, Poland, 2004. (In Polish)

47. Sobczyński, M. Zmienność Funkcji Granic Międzynarodowych na Ziemiach Polskich od Czasów Rzeczypospolitej Szlacheckiej do Przystapienia Polski do Układu z Schengen (Changeability of the International Borders Functions on Polish Territories from the Times of the Commonwealth (Poland \& Lithuania) until Accession of Poland to the Schengen Agreement). In Problematyka Geopolityczna Ziem Polskich (Geopolitical Problems of Polish Territories); Eberhardt, P., Ed.; Polish Academy of Sciences: Warsaw, Poland, 2008. (In Polish)

48. Kennard, A. Old Cultures, New Institutions. Around the New Eastern Border of the Europe; LIT: Berlin, Germany, 2010.

49. Kondracki, J. Geografia Regionalna Polski (Regional Geography of Poland); Polskie Wydawnictwo Naukowe: Warsaw, Poland, 1998. (In Polish)

50. Krukowska, R. Pojezierze Łęczyńsko-Włodawskie-Funkcja Turystyczna Regionu (Łęczna-Włodawa Lakeland-Tourist Function of the Region. Folia Tur. 2009, 21, 165-184.

51. Kozak, A.; Dmytruk, H.; Sokół, J.L.; Dąbrowski, D. Wizerunek Pojezierza Szackiego w Percepcji Ukraińskich Turystów (The Image of Shatsk Lakeland in the Perception of Ukrainian Tourists. In Obszary Przyrodniczo Cenne w Rozwoju Turystyki (Naturally Valuable Areas in the Development of Tourism); Jalinik, M., Bakier, S., Eds.; Oficyna Wydawnicza Politechniki Białostockiej: Białystok, Poland, 2020; pp. 245-259. (In Polish) [CrossRef]

52. Temereva, O.P. Рекреационно-туристическийПотенциалЗаказника «ПрибужскоеПолесье» (The Recreational and Tourist Potential of the Pribuzhskoye Polesie Biosphere Reserve). In Устойчивое развитие: региональныеаспекты: сборник материалов Международной научно-практической конференции молодых ученых в рамках года науки в Республике Беларусь(Sustainable Development: Regional Aspects: Material of the International Scientific and Practical Conference of Young Scientist with the Framework of the Year of Science in the Republic of Belarus); Volchek, A.A., Ed.; Ministry of Education of the Republic of Belarus, Brest State Technical University, Brest State University: Brest, Belarus, 2017; pp. 558-561. (In Russian)

53. Miszczuk, A. Uwarunkowania Rozwoju Turystyki Aktywnej na Obszarach Wiejskich w Polsko-białorusko-ukraińskim Regionie Transgranicznym (Condions for Development of Active Tourism in Rural Areas in the Polish-Belorusian-Ukrainian Cross-border Region). Studia KPZK PAN 2015, CLXVI, 9-27. (In Polish)

54. Biernat, S. Rola Granicy Państwowej w Przemianach Krajobrazowych Doliny Bugu (The Role of the State Border in the Landscape Changes of the Bug Valley). Pr. Kom. Kraj. Kulturowego. Gran. W Kraj. Kult. 2006, V, 173-182. (In Polish)

55. Główny Urząd Statystyczny (Statistics Poland). Available online: www.stat.gov.pl/BDL/podrupy/tablica (accessed on 18 August 2021). (In Polish)

56. Брестский районный исполнительный комитет(Brest District Executive Committee). Available online: www.brest.brest-region. gov.by (accessed on 18 August 2021). (In Russian)

57. Державна Служба Статистики України(State Statistics Service of Ukraine). Available online: www.ukrstat.gov.ua (accessed on 18 August 2021). (In Ukraininan) 
58. Bronisz, U.; Jakubowski, A. Społeczno-gospodarcze Uwarunkowania Rozwoju Przedsiębiorczości na Obszarze Polesia Zachodniego (Powiat Łęczyński i Włodawski) (Socio-economic Determinants of Entrepreneurship Development in the Araea of Western Polesie (Poviats Łęczyński and Włodawski). In Potencjał Polesia Lubelskiego a Zrównoważony Rozwój Transgranicznego Rezerwatu Biosfery Polesie Zachodnie (Potential of Polesie Lubelskie and the Sustainable Development of the Cross-border Biosphere Reserve Western Polesie); Dobrowolski, R., Mięsiak-Wójcik, K., Demczuk, P., Eds.; Starostwo Powiatowe w Łęcznej: Łęczna, Poland, 2015 ; pp. 69-81. (In Polish)

59. Anisiewicz, R. Z Przeszłości i Teraźniejszości Linii Kolejowej Brześć-Włodawa (From the Past and Present of Brest-Włodawa Railway Line). Wschód. Kwart. -Społeczno-Kult. 2021, 1, 20-25. (In Polish)

60. Anisiewicz, R. Tourists Assets of the Cross-border Railway Line Brest-Chełm. Pr. Kom. Geogr. Komun. PTG 2020, $23,19-31$. [CrossRef]

61. Wendt, J.A.; Pashkov, S.V.; Mydłowska, E.; Bógdał-Brzezińska, A. Political and Historical Determinants of the Differentiation of Entrepreneurial Ecosystems of Agritourism in Poland and Kazakhstan. Sustainability 2021, 13, 10487. [CrossRef]

62. Wschodni Szlak Rowerowy Green Velo (East of Poland Cycling Trail Green Velo). Available online: https:/ / greenvelo.pl (accessed on 22 August 2021).

63. Muzeum-Zespół Synagogalny We Włodawie (Museum-Synagogue Complex in Włodawa). Available online: www. muzeumwlodawa.pl (accessed on 4 September 2021). (In Polish)

64. Muzeum i Miejsce Pamięci w Sobiborze (Museum and Memory Site in Sobibór). Available online: www.sobibor-memorial.eu (accessed on 4 September 2021). (In Polish)

65. Stowarzyszenie-Lokalna Grupa Działania "Poleska Dolina Bugu" (Association-The Local Action Group "Poleska Dolina Bugu"). Available online: Dolina-bugu.pl (accessed on 9 September 2021). (In Polish)

66. Debbage, K. Geographies of Tourism Entrepreneurship and Innovation: Evolving ResearchAagenda. In A Research Agenda for Tourism Geography; Müller, D.K., Ed.; Edward Elgar Publishing: Cheltenham, UK; Northampton, MA, USA, 2019 ; pp. 79-88.

67. Audretsch, D.B.; Belitski, M. Entrepreneurial Ecosystems in Cities: Establishing the Framework Conditions. J. Technol. Transf. 2016, 42, 1030-1051. [CrossRef]

68. da Costa, T.G.; Teixeira, N.; Lisboa, I. Perceptions of Entrepreneurial Ecosystem in Tourism Sector: A Study in Municipality of Setúbal. In Handbook of Research on Entrepreneurship, Innovation, and Internationalization; Teixeira, N.M., da Costa, T.G., Lisboa, I.M., Eds.; IGI Global: Hershey, PA, USA, 2019; pp. 157-177.

69. Kline, C.; Duffy, L.; Clark, D. Fostering Tourism and Entrepreneurship in Fringe Communities: Unpacking Stakeholder Perceptions Towards Entrepreneurial Climate. Tour. Hosp. Res. 2020, 20, 3-17. [CrossRef] 